\title{
The Debt Versus Equity Debacle: A Proposal for Federal Tax Treatment of Corporate Cash Advances
}

\author{
Matthew T. Schippers*
}

\section{INTRODUCTION}

Since the 1969 codification of Internal Revenue Code section 385, ${ }^{1}$ much litigation has turned on the issue of whether a cash advance from the shareholders of a closely-held corporation to the corporation itself should be characterized as debt or equity for the corporation's federal income tax purposes. ${ }^{2}$ For instance, Corporation XYZ is formed by Shareholders $A$ and $B$, who are individuals each owning 50 percent of issued common stock. Immediately after the formation of the corporation, Shareholders $A$ and $B$ advance cash to the corporation for which they receive promissory notes. Here, the issue is whether the cash advance should be characterized as debt or equity for Corporation XYZ's federal income tax purposes.

These hypothetical facts mirror the facts of the Third Circuit's 1968 leading case, Fin Hay Realty Co. v. United States. ${ }^{3}$ Importantly, Fin Hay Realty listed sixteen factors - many of which courts use - to determine whether such a cash advance is debt or equity. ${ }^{4}$ One factor considered is

* J.D. Candidate, 2016, University of Kansas School of Law; C.P.A., 2011, State of Kansas; B.S., 2008, University of Kansas. I extend thanks to: R. Patrick Springer for reviewing multiple drafts of this piece as Comment Editor; Professors Stephen J. Ware, Quinton D. Lucas, and especially Martin B. Dickinson for their constructive feedback; the Kansas Law Review editorial board and staff members of Volume 64 for their hard work; my colleagues at Koch Industries, Inc. and Triplett, Woolf \& Garretson, LLC for their professional support; and my colleagues and peers of the J.L. Weigand Trust for their ongoing mentorship. Most importantly, I thank my family for supporting me throughout my academic and professional career.

1. I.R.C. $\$ 385$ (2012).

2. See infra Part II.B.

3. Fin Hay Realty Co. v. United States, 398 F.2d 694 (3d Cir. 1968).

4. Id. at 696. The factors include:

(1) the intent of the parties; (2) the identity between creditors and shareholders; (3) the extent of participation in management by the holder of the instrument; (4) the ability of the corporation to obtain funds from outside sources; (5) the "thinness" of the capital structure in relation to debt; (6) the risk involved; (7) the formal indicia of the arrangement; (8) the relative position of the obligees as to other creditors regarding the 
the "thinness" of the corporation's capital structure in relation to debt. ${ }^{5}$ Because no one factor is dispositive, litigation since Fin Hay Realty has produced uncertainty and inconsistency on this issue, ${ }^{6}$ resulting in increased levels of subjectivity on the part of the courts. ${ }^{7}$ Congress and the Department of the Treasury, moreover, have provided little guidance. $^{8}$ This confusion and lack of guidance is significant. For many corporations, millions of dollars are at stake because the Internal Revenue Service may re-characterize purported debt as equity, thus disallowing interest deductions ${ }^{9}$ and forcing double taxation of corporations' profits at the corporate level and the shareholder level. ${ }^{10}$

payment of interest and principal; (9) the voting power of the holder of the instrument; (10) the provision of a fixed rate of interest; (11) a contingency on the obligation to repay; (12) the source of the interest payments; (13) the presence or absence of a fixed maturity date; (14) a provision for redemption by the corporation; (15) a provision for redemption at the option of the holder; and (16) the timing of the advance with reference to the organization of the corporation.

Id.

5. Id.

6. See Willard B. Taylor et al., Three Views on Withdrawal of the Section 385 Regs., 20 TAX NoTES 495 (1983) ("The classification of interest in a corporation as debt or equity has been . . . an important source of litigation and uncertainty in the tax law."). See also ROBERT J. PERONI \& STEVEN A. BANK, TAXATION OF Business ENTERPRises: CASES AND MATERIals 157 (4th ed. 2012) (asserting that the Internal Revenue Code's rules for the characterization of debt and equity are "unsatisfactorily vague and uncertain"); Katherine Pratt, The Debt-Equity Distinction in a Second-Best World, 53 VAND. L. REV. 1055, 1087-88 (2000).

The debt-equity distinction causes numerous problems including complexity, uncertainty, and opportunities for tax arbitrage. Tax lawyers devote significant time to camouflaging equity-like instruments to resemble debt for tax purposes. Uncertainty about the tax consequences of innovative debt-equity hybrid securities inhibits the creation and sale of such securities. The inconsistent tax treatment of equivalent cash flows with different labels permits taxpayers to reap tax profits from paper transactions that otherwise produce no economic gain or loss. The debt-equity distinction thus distorts behavior.

Id.

7. Margaret A. Gibson, Comment, The Intractable Debt/Equity Problem: A New Structure for Analyzing Shareholder Advances, 81 Nw. U.L. REV. 452, 453-54 (1987) ("The courts themselves have recognized that their standards are largely subjective, [and] that the rule of stare decisis has eroded in this area ....").

8. See Jeffrey D. Eicher \& Leo N. Hitt, Section 385: Debt by Any Other Name ..., 65 TAX NOTES 1033 (1994) (asserting that courts have "struggled without guidance to answer the debt/equity issue").

9. Kristina Dautrich Reynolds, Intercompany Debt - Is It Even Debt?, ALvareZ \& MARSAL: TAX ADVISOR WKLY. (Oct. 2, 2013), http://www.alvarezandmarsal.com/intercompany-debt-it-evendebt2.

10. See PERONI \& BANK, supra note 6, at 192-93, 196 (describing double taxation of corporate profits by noting: (1) the distribution of corporate profits is not deductible, thus preserving corporate-level tax; and (2) under section 1(h)(11), shareholders are taxed on the distribution of profits in the form of a dividend, which is a "distribution of property made by a corporation to its shareholders ... out of its earnings and profits" under section 316, at the same rate of tax that applies to long-term capital gains). 
Courts have looked to many factors to determine whether a cash advance is debt or equity. ${ }^{11}$ However, the ultimate inquiry is whether the corporation-shareholder transaction has the economic reality of a debtorcreditor relationship. ${ }^{12}$ Courts measure economic reality by determining "whether the transaction would have taken the same form had it been between the corporation and an outside lender."13 To determine if they will enter transactions, outside lenders primarily consider the risk associated with the borrowing corporation, measured by the corporation's "thinness" of capital structure and debt-to-equity ratio. ${ }^{14}$

Because the tax characterization of a cash advance is an issue of economic reality exemplified by the "thinness" of capital structure of the corporation, ${ }^{15}$ the Secretary of the Treasury should prescribe regulations under section 385 to establish guidance for thin capitalization. The proposed regulations should define thin capitalization as a principal factor in the analysis. In addition, because thin capitalization is most objectively exemplified by the debt-to-equity ratio, the proposed regulations should define the calculation of the debt-to-equity ratio using the fair market value of the corporation's liabilities and shareholders' equity.

Part II of this Comment examines the legislative, regulatory, and case law history of the debt versus equity inquiry. Part III argues that the "thinness" of capital structure of the closely-held corporation is a

11. See, e.g., Estate of Mixon v. United States, 464 F.2d 394, 402 (5th Cir. 1972) (using a thirteen-factor test); Delta Plastics, Inc. v. Comm'r, 85 T.C.M. (CCH) 940, 943 (2003) (using a tenfactor test). See also Dixie Dairies Corp. v. Comm'r, 74 T.C. 476, 493 (1980) (describing factors considered by other courts); A.R. Lantz Co. v. United States, 424 F.2d 1330, 1333 (9th Cir. 1970) (using an eleven-factor test).

12. See Litton Bus. Sys., Inc. v. Comm'r, 61 T.C. 367, 377 (1973). See also Smithco Eng'g, Inc. v. Comm'r, 47 T.C.M. (CCH) 966, 969 (1984) ("[T]he ultimate question . . . is whether there was a genuine intent to create a debt, with a reasonable expectation of repayment, and whether that intention comports with the economic reality of a debtor-creditor relationship." (citing Litton, 61 T.C. at 377)).

13. Scriptomatic, Inc. v. United States, 555 F.2d 364, 367 (3d Cir. 1977), aff'g 397 F. Supp. 753 (E.D. Pa. 1975).

14. See Bauer v. Comm'r, 748 F.2d 1365, 1369 (9th Cir. 1984) ("The purpose of examining the debt-to-equity ratio in characterizing a stockholder advance is to determine whether a corporation is so thinly capitalized that a business loss would result in an inability to repay the advance; such an advance would be indicative of venture capital rather than a loan." (citing Gilbert v. Comm'r, 248 F.2d 399, 407 (2d Cir. 1957))). See also William J. Carney, Corporate FinANCE: PRINCIPLES AND PRACTICE 51 (Robert C. Clark et al. eds., 3d ed. 2015) ("[Financial leverage ratios] are employed by creditors in analyzing whether to extend credit to an enterprise, and by attorneys drafting bond indentures, to provide bondholders with reasonable safeguards."); id. at 55 (describing the debt-to-equity ratio as a financial leverage ratio "used a great deal to describe the leverage of a firm").

15. See supra text accompanying notes 11-14. 
principal factor in the debt versus equity analysis. In addition, Part III argues that the Secretary of the Treasury should propose regulations regarding the calculation of the debt-to-equity ratio to provide more objective guidance to corporate taxpayers. Finally, Part III considers the beneficial effects of proposing regulations under section 385 .

\section{BACKGROUND}

\section{A. Background of Debt Versus Equity Characterization}

\section{Tax Implications of Debt or Equity Characterization for Corporate Financing}

In forming capital structures, corporations can finance operations by issuing either debt or equity capital. ${ }^{16}$ While neither the Internal Revenue Code (the Code) nor Treasury regulations contain express definitions of debt and equity, ${ }^{17}$ courts define debt as "an unqualified obligation to pay a sum certain at a reasonably close fixed maturity date along with a fixed percentage in interest payable regardless of the debtor's income or lack thereof." 18 In contrast, courts define equity as an instrument held by a corporation's shareholder, "who seeks to make an investment and to share in the profits and risks of loss in the venture." 19 Thus, the corporation issues debt to creditors in exchange for cash or other property and pays interest to creditors over the term of the debt instrument. ${ }^{20}$ Alternatively, the corporation issues stock to shareholders and pays dividends to shareholders in return for their investment. ${ }^{21}$

16. Pratt, supra note 6, at 1059. See also PERONI \& BANK, supra note 6, at 154-55 ("A corporation's capital structure consists of the securities issued by the corporation in exchange for the cash or other property or services contributed, or to be contributed, to it. The classic components of a capital structure include stock, which is understood to represent the ownership, or equity, interest in the corporation, and debt, which reflects a creditor interest ....") (emphasis added).

17. PERONI \& BANK, supra note 6, at 158 ("There is presently no definition in the Code or the regulations which can be used to determine whether an interest in a corporation constitutes debt or equity for tax purposes. Such a determination must be made under principles developed in case law.").

18. Gilbert v. Comm'r, 248 F.2d 399, 402 (2d Cir. 1957).

19. Bauer, 748 F.2d at 1367 (citing A.R. Lantz Co. v. United States, 424 F.2d 1330, 1334 (9th Cir. 1970)). See also William T. Plumb, Jr., The Federal Income Tax Significance of Corporate Debt: A Critical Analysis and a Proposal, 26 TAX L. REV. 369, 404 (1970) ("[The shareholder] takes the risk, and profits from success.").

20. Pratt, supra note 6, at 1059-60. See also PERONI \& BANK, supra note 6, at 155-56 (discussing the various extensions of credit to a corporation).

21. Pratt, supra note 6, at 1059-60. In the event of bankruptcy, the holder of the debt instrument "would regain his investment in liquidation as a creditor of the corporation before the equity holders would receive any of their investment." Meredith R. Conway, With or Without You: 
Whether a cash advance is characterized as debt or equity has critical tax implications. The Code imposes federal income tax on most U.S. corporations with few exceptions. ${ }^{22}$ The Code provides different tax treatment of debt and equity in several contexts. ${ }^{23}$ However, the deductibility of interest from bona fide indebtedness is the main reason corporate taxpayers and the Internal Revenue Service (IRS) focus on debt versus equity questions. ${ }^{24}$ The Code allows a corporation to take a tax deduction for "all interest paid or accrued... on indebtedness." 25 Yet, the Code does not contain a similar deduction for dividends that corporations pay to shareholders for their equity investments. ${ }^{26}$ Therefore, corporate earnings are taxed at both the corporate entity level (via corporate taxable income) and the individual shareholder level (via shareholder dividend income), resulting in double taxation. ${ }^{27}$

Debt and Equity and Continuity of Interest, 15 STAN. J.L. BUS. \& FIN. 261, 291 (2010) (comparing and contrasting aspects of traditional debt with traditional equity). See also PERONI \& BANK, supra note 6, at 155 ("Common stock represents the residual interest in the corporation. Thus, the common stockholders are entitled to all of the corporate profits and increase in value ....").

22. I.R.C. § 11 (2012). This Comment's scope refers to closely-held "C" corporations, which are subject to United States federal income tax. A "C" corporation is a "corporation which is not an S corporation for such year." I.R.C. § 1361(a)(2). An "S" corporation is "a small business corporation for which an election under section 1362(a) is in effect for such year." I.R.C. $\S$ 1361(a)(1). As a result of the election under section 1362(a), an S corporation is not subject to corporate income tax. See I.R.C. $§ 1363$ (a). To be eligible for this exception from corporate income tax, the corporation must be domestic and must not: "(A) have more than 100 shareholders, (B) have as a shareholder a person... [subject to few exceptions] who is not an individual, (C) have a nonresident alien as a shareholder, and (D) have more than 1 class of stock." I.R.C. $\S$ 1361(b)(1)(A)-(D).

23. These contexts include the bad debt deduction and worthless stock capital loss. First, debt versus equity classification is important to proving a creditor-taxpayer's bad debt deduction under section 166, which provides that a deduction shall be allowed for "any debt which becomes worthless within the taxable year." I.R.C. § 166(a)(1). To be entitled to the deduction, the taxpayer must prove a bona fide debt, which "arises from a debtor-creditor relationship based upon a valid and enforceable obligation to pay a fixed or determinable sum of money." Treas. Reg. § 1.166-1(c) (as amended in 1986). See also Calumet Indus., Inc. v. Comm'r, 95 T.C. 257, 284 (1990). Second, debt versus equity classification is important to establishing a creditor-taxpayer's worthless stock capital loss under section $165(\mathrm{~g})$, which states that the loss from a worthless security which is a capital asset shall "be treated as a loss from the sale or exchange ... of a capital asset." I.R.C. § $165(\mathrm{~g})(1)$. Thus, "worthless stock is treated as a capital loss" because corporate stock is generally treated as a "capital asset" as defined in section 1221. See Lane v. United States, No. 80-G-1442-S, 1983 WL 1636, at *1 (N.D. Ala. July 6, 1983), aff'd, 742 F.2d 1311 (11th Cir. 1984). See also William B. Barker, A Common Sense Corporate Tax: The Case for a Destination-Based, Cash Flow Tax on Corporations, 61 CATH. U.L. REV. 955, 964 (2012) ("[T]he disparate treatment of debt and equity remains one of the most important features of corporate taxation.").

24. Thomas D. Greenaway \& Michelle L. Marion, A Simpler Debt-Equity Test, 66 TAX LAW. 73,75 (2012).

25. I.R.C. $\S 163(a)$.

26. See I.R.C. \$§ 162, 301-18.

27. See supra text accompanying note 10. See also David P. Hariton, Distinguishing Between Equity and Debt in the New Financial Environment, 49 TAX L. REV. 499, 499 (1994) (asserting that 
Because a deduction is allowed for interest paid or accrued on indebtedness, "debt is usually preferable to stock" in a corporation's capital structure due to tax savings. ${ }^{28}$ For the corporation, the amount of tax savings is the amount of the interest deduction multiplied by the issuing corporation's tax rate. ${ }^{29}$ For the individual shareholder, the amount of interest received is taxable as gross income at the shareholder's ordinary income rate. ${ }^{30}$ However, if the IRS recharacterizes purported debt into equity, then the distribution will be treated as a dividend with no associated deduction for the corporation. For the individual shareholder receiving qualified dividend income from the corporation, the tax rate is lowered from the ordinary income rateas high as 39.6 percent in 2015 - to the long-term capital gain rateeither 0,15 , or 20 percent. $^{31}$ While this tax rate reduction for individual

double taxation is "the greatest anomaly of the U.S. tax system"); PERONI \& BANK, supra note 6, at 156 ("[O]n balance there is normally a significant bias in favor of the use of debt rather than equity. Corporate profits distributed on stock are subject to the double tax imposed upon corporations in this country .... . On the other hand, earnings distributed on debt avoid the double tax.").

28. Roger P. Becker, Classification of an Interest in a Corporation as Stock or IndebtednessNew Regulations to Internal Revenue Code Section 385, 29 U. KAN. L. REV. 213, 217 (1981). See also Barker, supra note 23, at 965-66 ("[T]he combination of tax incentives and debt financing produces a substantial government subsidy to corporations."). William Plumb, Jr. suggested that U.S. corporate tax law should treat debt and equity in a similar way for tax purposes to eliminate the disparate impact between the interest deduction and double taxation of corporate dividends. See Plumb, supra note 19, at 398-404 (suggesting tax treatment of interest as nondeductible expense, or dividends as deductible expense). See also Robert H. Scarborough, How Derivatives Use Affects Double Taxation of Corporate Income, 55 TAX L. REV. 465, 480-81 (2002).

Increasing the ratio of debt to equity increases the value of the firm by reducing the burden of the corporate tax, but only up to the point at which the increased expected costs of financial distress resulting from increased leverage outweigh this benefit. The more debt a corporation issues, and thus the greater the benefit of the tax shield, the more it is worth - but only up to a point. At some point the increased expected costs of financial distress from replacing equity with debt begin to outweigh the tax benefits of increased leverage. Thus, the choice of optimal capital structure is widely seen as requiring a tradeoff of tax benefits against expected bankruptcy risk.

Id. (footnote omitted).

29. See Joint Comm. on TAxation, Present Law and Background Relating to Tax TREATMENT OF BUSINESS DEBT 64 (2011) [hereinafter JCT], http://waysandmeans.house.gov/ UploadedFiles/Barthold_Testimony_Business_Debt_7.13.pdf.

30. I.R.C. $\S 61(\mathrm{a})(4)$. In addition to the ordinary income rate, individual taxpayers may be subject to an additional 3.8 percent tax imposed on net investment income, including interest income, if the taxpayer exceeds a certain threshold based upon adjusted gross income. See I.R.C. $\$$ 1411.

31. I.R.C. $§ 1(\mathrm{~h})(11)(\mathrm{B})$. Section $1(\mathrm{~h})(11)$ reduced the tax rate for qualified dividend income - defined as "dividends received during the taxable year from (I) domestic corporations, and (II) qualified foreign corporations" - to the long-term capital gain rate. For individual taxpayers in the 10 or 15-percent tax brackets, the qualified dividend income tax rate is 0 percent. I.R.C. $\S$ 1(h)(1)(B), (11)(A). For individual taxpayers in the 25, 28, 33, or 35-percent tax brackets, the qualified dividend income tax rate is 15 percent. I.R.C. $\$ 1(\mathrm{~h})(1)(\mathrm{C}),(11)(\mathrm{A})$. For individual taxpayers in the 39.6 percent tax bracket, the qualified dividend income tax rate is 20 percent. I.R.C. 
shareholders may diminish the disadvantage of double taxation, there is still incentive to avoid payment of dividends to individual shareholders because "corporate profits remain more heavily taxed overall than are other forms of income." 32 In contrast, for the corporate shareholder receiving dividend income, the Code grants a special deduction. ${ }^{33}$ If the corporate shareholder owns more than 80 percent of the voting power and value of stock of a domestic corporation and is, thus, a member of the same affiliated group as the corporation, the corporate shareholder is granted a deduction for the full amount of dividends received. ${ }^{34}$

While the Code grants a deduction for interest on debt, it also imposes limits on this deduction. ${ }^{35}$ For instance, section $163(\mathrm{j})$ provides that interest paid by a corporation to a related tax-exempt or foreign entity is not deductible if: (1) the corporation has a debt-to-equity ratio as of the close of the year in excess of 1.5 to 1; and (2) the corporation's net interest expense is greater than 50 percent of its adjusted taxable income. $^{36}$ Further, Code regulations do not allow a deduction for "[i]nterest calculated for ... purposes on account of capital or surplus invested in the business which does not represent a charge arising under an interest-bearing obligation." 37

Because the interest deduction is so attractive to the corporate taxpayer, courts have closely examined cash advances between a parent

§ 1(h)(1)(D), (11)(A). Section 1(h)(11) was implemented in 2003. See Jobs and Growth Tax Relief Reconciliation Act of 2003, Pub. L. No. 108-27, § 302, 117 Stat. 752, 760-64 (2003). In addition to the long-term capital gain rate, the individual taxpayer may be subject to an additional 3.8 percent tax imposed on net investment income, including dividend income, if the taxpayer exceeds a certain threshold based upon adjusted gross income. See I.R.C. § 1411.

32. PERONI \& BANK, supra note 6, at 193-94.

33. See I.R.C. \$ 243.

34. I.R.C. $\S \S 243(a)(3)-(b), 1504(a)$. If the corporate shareholder owns between 20 and 80 percent of the stock of the corporation (by vote and value), then the corporate shareholder is granted deduction of 80 percent of the dividends received. I.R.C. $\$ 243(\mathrm{a})(1)$, (c). If the corporate shareholder owns less than 20 percent of the stock of the corporation (by vote and value), then the corporate shareholder is granted a deduction of 70 percent of the dividends received. I.R.C. $\S$ 243(a)(1).

35. See Scarborough, supra note 28, at 490 ("[T] $]$ he tax law places limits on a corporation's ability to replace equity with conventional (that is, noncontingent, full-recourse) debt to minimize double taxation of corporate income.").

36. I.R.C. $§ 163(\mathrm{j})$. Section 163(j) applies to a narrow subset of U.S. taxpayers who do not meet the statutory safe harbor with a debt-to-equity ratio of 1.5 to 1 , pay "disqualified interest," and have "excess interest expense." See id. This Comment applies to a wider scope of taxpayers covered by section 385 . As another example of where the Code limits the deductibility of interest, section 163(e)(5) denies full deductibility for original issue discount on debt instruments if (1) the instrument has a yield that exceeds the applicable federal rate plus 5 percentage points; (2) the instrument has a term of more than five years; and (3) as of the end of the fifth year more than one year of original issue discount is deferred. I.R.C. § 163(e)(5), (i).

37. Treas. Reg. § 1.163-1(c) (as amended in 1976). 
corporation (acting as a shareholder) and a subsidiary corporation. ${ }^{38}$ The parent's control over the subsidiary poses an opportunity to create "fictional debt." 39 Courts emphasize the importance of an ongoing debtor-creditor relationship in determining whether to allow an interest deduction. ${ }^{40}$ In addition, courts focus on objective evidence- such as payment terms and a maturity date on the debt instrument - to determine whether a purported loan is bona fide indebtedness or an equity investment. $^{41}$

\section{Debt Versus Equity Characterization in Corporate Financial Markets}

Early case law regarding debt versus equity characterizations "developed... in a relatively static financial environment" ${ }^{\text {" } 2}$ where financial instruments were more easily identified as debt or equity than they are today. While the debt versus equity issue generally arose in the context of small, closely-held corporations like the corporation in Fin Hay Realty, ${ }^{43}$ the issue has transformed in response to changes in financial markets. Newer financial instruments, such as convertible debt and preferred stock, have features of both debt and equity and thus cause increased complexity for the debt versus equity distinction. ${ }^{44}$ Moreover,

38. See, e.g., Racal Elecs., Inc. v. Comm'r, 60 T.C.M. (CCH) 756, 764-65 (1990).

39. See Gilboy v. Comm'r, 37 T.C.M. (CCH) 510, 515 (1978) (asserting that advances to a closely held corporation by its shareholders are subject to particular scrutiny because the "absence of arm's-length dealing provides the opportunity to contrive a fictional debt shielding the real essence of the transaction and obtaining benefits unintended by the statute").

40. See Green Leaf Ventures, Inc. v. Comm'r, 69 T.C.M. (CCH) 2342, 2350-51 (1995) (asserting that the interest deduction "ceases to be a real cost if with the passage of time it becomes apparent that the parties have no intention of continuing the debtor-creditor relationship"). See also Cuyuna Realty Co. v. United States, 382 F.2d 298, 301-02 (Ct. Cl. 1967) (“[T]he character of indebtedness may vanish when the parent and the subsidiary cease acting like debtors and creditors ....”).

41. See Indmar Prods. Co. v. Comm'r, 444 F.3d 771, 780 (6th Cir. 2006) (asserting that the desire to avoid taxes acts "as a flag to the Commissioner and courts to look closely at the transaction for any objective indicia of debt”). See also H \& M, Inc. v. Comm'r, 104 T.C.M. (CCH) 452, 458 60 (2012) (characterizing a cash advance as equity where the promissory note included neither payment terms nor a maturity date).

42. Hariton, supra note 27, at 500.

43. Fin Hay Realty Co. v. United States, 398 F.2d 694, 695 (3d Cir. 1968).

44. See Discussion Memorandum, An Analysis of Issues Related to Distinguishing between Liability and Equity Instruments and Accounting for Instruments with Characteristics of Both, 94 FIN. ACCT. SERIES 1, 2 (1990) ("[D]ebt that is convertible at the election of the holder into common stock of the issuer combines characteristics of both a liability and an equity instrument .... [S]ome issues of preferred stock have maturity amounts and dates at which the issuing enterprise must redeem them for cash."). See also Scarborough, supra note 28, at 528.

Both the tax law and corporate finance theory traditionally have viewed corporate capital structure as made up of debt and equity. This model breaks down when confronted with instruments that are not classified as equity for tax purposes, but reference the issuing 
following the changes in the financial marketplace during the 1980s, several different types of financial instruments have arisen, including high yield debt, hybrid debt, and options. ${ }^{45}$

In addition to different types of debt and equity instruments, leveraged buybacks of corporate stock increased during the 1980s as a way to replace equity with debt to utilize interest deductions. ${ }^{46}$ As a result, on average, corporate capital structures contained more debt and less equity. ${ }^{47}$ In the 1990 s, derivative transactions increased in the financial marketplace, causing an added level of complexity to distinguishing between equity and debt. ${ }^{48}$

Finally, an increase in international business has resulted in an increase in cash transfers from foreign parent entities to foreign-owned U.S. companies, which then claim a deduction for interest expense. ${ }^{49}$ For

corporation's shares, earnings, or business risks. Instruments in this third category include swaps, options, and forward contracts on a corporation's own stock, earningslinked contingent debt, more traditional convertible debt, and derivatives used to shift specific business risks from the corporation to other parties. Id.

45. Hariton, supra note 27, at 500. For instance, high yield debt is "subordinated to other creditor interests," so that in the case of bankruptcy, high yield debt holders are senior only to equity holders. Pratt, supra note 6, at 1071. Because of their low priority, high yield bondholders are promised a disproportionately high interest rate, which causes the high yield bonds to bear strong similarities with preferred stock, a type of equity security. Id. See also John Herbert Roth, Comment, The Disparate Treatment of Nonqualified Preferred Stock: Yet Another Tax Classification Nightmare?, 32 CuMB. L. REV. 605, 636 (2001-02) (““[D]ebt' and 'equity' are labels for the two edges of a spectrum, between which lie an infinite number of investment instruments, each differing from its nearest neighbor in barely perceptible ways." (quoting BORIS I. BITTKER \& JAMES S. Eustice, Federal Income Taxation of Corporations \& Shareholders § 4.02[1] (7th ed. 2000))).

46. See Eicher \& Hitt, supra note 8 ("[T] (T) Tax Code was at least partially responsible for the acquisition and takeover frenzy of the 1980s, which relied heavily on leveraged transactions and the resulting interest expense deductions."). See also Scarborough, supra note 28, at 529 ("The 1980's saw increased use of leveraged buy-backs of corporate stock as a way to replace equity with debt to reduce double taxation of corporate income. Corporations used leveraged buy-backs of their stock as a form of self-help integration of the corporate and investor taxes.").

47. Pratt, supra note 6, at 1070 ("During the 1980s, public corporations began to issue significantly more debt. This debt was frequently issued in exchange for outstanding stock of the corporation. The result was that corporate capital structures, on average, included more debt and less equity.").

48. Hariton, supra note 27, at 500-01. See also Scarborough, supra note 28, at 474 (describing the following types of derivatives: forward contract on corporate shares, an equity swap referencing to corporate shares, and "derivative[s] referencing a market index that correlates with [a corporation's] share price"').

49. See Thomas A. Butera, Laidlaw: The Debt vs. Equity Classification Issue Resurfaces, $16 \mathrm{~J}$. TAX'N INV. 185, 185 (1999) (“[M] oney is typically transferred from the foreign parent company, or one of its subsidiaries, to the U.S. subsidiary in a transaction characterized by the parties as indebtedness."). 
example, in Laidlaw Transportation, Inc. v. Commissioner,${ }^{50}$ a Canadian parent company formed a Dutch subsidiary to transfer funds, in the form of debt, to a group of U.S. subsidiaries. ${ }^{51}$ Holding that the funds should be characterized as equity for U.S. federal income tax purposes, the Tax Court disallowed the U.S. subsidiaries' significant tax deduction for interest expense in the amount of $\$ 133$ million. ${ }^{52}$ Considering these changes in the financial marketplace, many of the traditional debt versus equity factors, discussed below, are no longer relevant to the analysis. ${ }^{53}$

\section{Legislative and Regulatory Background of the Debt Versus Equity Characterization}

The debt versus equity issue has a decades-long legislative and regulatory history, the apex of which was Congress's 1969 enactment of Code section $385 .^{54}$ The 1969 enactment authorized the Treasury to prescribe regulations defining corporate stock and debt for U.S. federal income tax purposes. ${ }^{55}$ The Senate Report noted the difficulty of enacting comprehensive and specific statutory rules to distinguish between debt and equity. ${ }^{56}$ The statute itself defers to the Secretary of the Treasury to promulgate guidelines. ${ }^{57}$

Section 385(b) states that "[t]he regulations prescribed under this section shall set forth factors which are to be taken into account in determining with respect to a particular factual situation whether a debtor-creditor relationship exists or a corporation-shareholder relationship exists." ${ }^{\text {,58 }}$ Section 385 (b) contains five factors that the Secretary "may include" in establishing regulations:

\footnotetext{
50. Laidlaw Transp., Inc. v. Comm'r, 75 T.C.M. (CCH) 2598 (1998).

51. See id. at 2598-99, 2602-03.

52. Id. at $2598-99,2624$.

53. See Greenaway \& Marion, supra note 24 , at 80 ("[T]he old debt-equity factors are vulnerable to criticism for being unsuitable for distinguishing debt from equity in today's world given changes in structured finance.").

54. See I.R.C. § 385 (2012).

55. See id. Prior to this enactment, the House Report on the 1954 Code attempted to distinguish between stock and debt by defining the terms "participating stock," "nonparticipating stock," and "securities." See H.R. REP. No. 83-1337, at 4061 (1954). However, the Senate observed that any attempt to write statutory definitions for corporate stocks and securities for tax purposes would be frustrated by the interchangeable characteristics that can be given to these instruments. See S. REP. NO. 83-1622, at 4672-73 (1954).

56. See S. REP. No. 91-552, at 2034 (1969).

57. See id.; I.R.C. $§ 385$ (a) ("The Secretary is authorized to prescribe such regulations as may be necessary or appropriate to determine whether an interest in a corporation is to be treated for purposes of this title as stock or indebtedness ....").
}

58. I.R.C. $\S 385(\mathrm{~b})$. 
1. whether there is a written unconditional promise to pay on demand or on a specified date a sum certain in money in return for an adequate consideration in money or money's worth, and to pay a fixed rate of interest,

2. whether there is subordination to or preference over any indebtedness of the corporation,

3. the ratio of debt to equity of the corporation,

4. whether there is convertibility into the stock of the corporation, and

5. the relationship between holdings of stock in the corporation and holdings of the interest in question.

Notably, one of the five factors is the debt-to-equity ratio, a concept that gained more attention when the Treasury proposed regulations under section 385 on March 24, 1980. ${ }^{60}$ The Treasury provided for an objective debt-to-equity ratio by proposing: "[A] corporation's debt is not excessive if ... [t] he corporation's outside ratio is less than or equal to $10: 1$, and ... [t] he corporation's inside ratio is less than or equal to 3:1." ${ }^{\prime}$ The term outside ratio refers to "the ratio that the liabilities, excluding trade accounts payable and other accrued payables, bear to the stockholders' equity." 62 In contrast, the term inside ratio refers to the ratio of liabilities - excluding trade accounts payable, other accrued payables, and liabilities to independent creditors - to the stockholders' equity. ${ }^{63}$

The proposed regulations also included provisions for the calculation of the debt-to-equity ratio, which had been an area of dispute. ${ }^{64}$ In the calculation of both the outside and inside ratios, the proposed regulations disregarded trade accounts payable, accrued operating expenses, and similar items. ${ }^{65}$ The Treasury's rationale was that trade accounts payable and accrued expenses vary widely during the year; consequently, if these figures were included in debt, "one of the principal purposes of the regulations, which is to provide a high degree of certainty for

\footnotetext{
59. I.R.C. § 385(b)(1)-(5) (emphasis added).

60. See Eicher \& Hitt, supra note 8 (providing a brief history of the proposed and withdrawn section 385 regulations).

61. Prop. Treas. Reg. $§ 1.385-6$ (g)(3), 47 Fed. Reg. 164, 182 (Jan. 5, 1982).

62. Becker, supra note 28 , at 228.

63. Id.

64. See Gibson, supra note 7, at 482 (noting that there is "great ambiguity" in determining the inputs into the debt-to-equity ratio).

65. Prop. Treas. Reg. § 1.385-6(h)(1)(i), 47 Fed. Reg. 164, 183 (Jan. 5, 1982).
} 
corporations," would be defeated. ${ }^{66}$

Despite the Treasury's efforts, the final regulations proved controversial for "being too anti-business,"67 and revised regulations were published on January $5,1982 .{ }^{68}$ Subsequently, on July 6,1983 , the final regulations and proposed revisions were withdrawn; thus, the Treasury failed to enact regulations under section $385 .^{69}$ In 1989, Congress amended section 385 to authorize the Treasury to issue regulations that would bifurcate instruments into equity and debt portions, ${ }^{70}$ but these regulations have not been issued. In 1992, Congress amended section 385 by adding subsection (c), which binds the issuing taxpayer-but not the IRS - to the "characterization (as of the time of issuance) by the issuer as to whether an interest in a corporation is stock or indebtedness."71 Since the enactment of section 385, the IRS has rarely issued revenue rulings and notices in regards to the debt versus equity issue. ${ }^{72}$

In April 1994, however, the IRS did issue Notice $94-47,{ }^{73}$ one of few official notices providing guidance on the debt versus equity issue. Notice 94-47 was issued in response to transactions formed in such a way as to be treated as debt for federal income tax purposes but as equity

66. Supplementary Information to Proposed Regulations, 45 Fed. Reg. 18,957, 18,959 (Mar. 24, 1980).

67. Robert J. Misey Jr., An Unsatisfactory Response to the International Problem of Thin Capitalization: Can Regulations Save the Earnings Stripping Provision?, 8 INT'L TAX \& BUS. LAW. 171, 173 (1991). See also PERONI \& BANK, supra note 6, at 162-63 (noting the "flood of criticism" resulting from the regulations, and recognizing the odd outcome of the regulations' approach to bifurcation (where the investment in the corporation is allocated between stock and debt), which reduced the principal amount of purported debt rather than the interest deduction).

68. See Prop. Treas. Reg. $\S \S 1.385-1$ to $1.385-12$, 45 Fed. Reg. 18,957 (Mar. 24, 1980), revised, 45 Fed. Reg. 86,438 (Dec. 31, 1980), revised and reproposed as Prop. Treas. Reg. §§ 1.3850 to 1.385-8, 47 Fed. Reg. 164 (Jan. 5, 1982), withdrawn, 48 Fed. Reg. 31,053 (July 6, 1983).

69. See Eicher \& Hitt, supra note 8 (providing a brief history of the proposed and withdrawn section 385 regulations).

70. Omnibus Budget Reconciliation Act of 1989, Pub. L. No. 101-239, § 7208, 103 Stat. 2106, 2337 (1989). Subsection (a) was amended by inserting "(or as in part stock and in part indebtedness)" at the end of the subsection, so the final language states: "The Secretary is authorized to prescribe such regulations as may be necessary or appropriate to determine whether an interest in a corporation is to be treated for purposes of this title as stock or indebtedness (or as in part stock and in part indebtedness).” I.R.C. § 385(a) (2012).

71. I.R.C. § 385(c). See also Energy Policy Act of 1992, Pub. L. No. 102-486, § 1936, 106 Stat. 2776, 3032 (1992) (amending $§ 385$ by adding subsection (c), applicable "to instruments issued after the date of enactment").

72. For instance, in 1983, the IRS issued Revenue Ruling 83-98 regarding adjustable rate convertible notes (ARCNs). The ruling takes the position that "the ARCNs were equity, not debt, because there was no debtor-creditor relationship between the issuer and the holders of the ARCNs." Pratt, supra note 6, at 1082 (citing to Rev. Rul. 83-98, 1983-2 C.B. 40).

73. I.R.S. Notice $94-47,1994-1$ C.B. 357. 
for regulatory, rating agency, or financial accounting purposes. ${ }^{74}$ The Notice listed the following factors - including thin capitalization - that may be considered in making the determination of an instrument for federal income tax purposes:

1. whether there is an unconditional promise on the part of the issuer to pay a sum certain on demand or at a fixed maturity date that is in the reasonably foreseeable future;

2. whether holders of the instruments possess the right to enforce the payment of principal and interest;

3. whether the rights of the holders of the instruments are subordinate to rights of general creditors;

4. whether the instruments give the holders the right to participate in the management of the issuer;

5. whether the issuer is thinly capitalized;

6. whether there is identity between holders of the instruments and stockholders of the issuer;

7. the label placed upon the instruments by the parties; and

8. whether the instruments are intended to be treated as debt or equity for non-tax purposes, including regulatory, rating agency, or financial accounting purposes. $^{75}$

Since the issuance of Notice $94-47$, there have been no major regulatory debt versus equity developments. ${ }^{76}$ As a result, there is no comprehensive statutory or regulatory guidance on what makes a cash advance equity or debt. ${ }^{77}$

\section{B. Case Law of the Debt versus Equity Characterization}

\section{Circuit Courts' Various Approaches to Debt versus Equity Characterization}

Because Congress and the Treasury have not defined debt and equity, there is lack of uniformity regarding this issue among courts - even in

\footnotetext{
74. Id.

75. Id. (emphasis added).

76. Greenaway \& Marion, supra note 24, at 79.

77. Id.
} 
cases where creditor-debtor relationships appear substantially similar. ${ }^{78}$ Circuit courts have not settled on a single approach or list of factors to consider in answering the debt versus equity question. ${ }^{79}$ Although many of the circuit courts cite to the majority of the sixteen factors from Fin Hay Realty, ${ }^{80}$ the circuit courts have differing lists of factors to which they look to answer the debt versus equity inquiry. ${ }^{81}$ The Sixth Circuit ${ }^{82}$ and Ninth Circuit $^{83}$ use an eleven-factor test. The Fifth Circuit and Eleventh Circuit use a thirteen-factor test, ${ }^{84}$ and the Eighth Circuit uses a

78. Tyler v. Tomlinson, 414 F.2d 844, 847 (5th Cir. 1969) (asserting that the divergent case law regarding debt versus equity "has resulted in a lack of decisional uniformity even in cases where the individual creditor-debtor relationships exhibit ostensible similitude").

79. See Indmar Prods. Co. v. Comm'r, 444 F.3d 771, 776 (6th Cir. 2006).

80. See Fin Hay Realty Co. v. United States, 398 F.2d 694, 696 (3d Cir. 1968). See also supra note 4 and accompanying text.

81. See infra notes $82-85$ and accompanying text.

82. See Roth Steel Tube Co. v. Comm'r, 800 F.2d 625, 630 (6th Cir. 1986) (noting no one factor of an eleven-factor test is dispositive and the test must be applied to "the particular circumstances of each case"). The factors include:

(1) the names given to the instruments, if any, evidencing the indebtedness; (2) the presence or absence of a fixed maturity date and schedule of payments; (3) the presence or absence of a fixed rate of interest and interest payments; (4) the source of repayments; (5) the adequacy or inadequacy of capitalization; (6) the identity of interest between the creditor and the stockholder; (7) the security, if any, for the advances; (8) the corporation's ability to obtain financing from outside lending institutions; (9) the extent to which the advances were subordinated to the claims of outside creditors; (10) the extent to which the advances were used to acquire capital assets; and (11) the presence or Id. absence of a sinking fund to provide repayments.

83. See Bauer v. Comm'r, 748 F.2d 1365, 1368 (9th Cir. 1984) (utilizing an eleven-factor test). The factors include:

(1) the names given to the certificates evidencing the indebtedness; (2) the presence or absence of a maturity date; (3) the source of the payments; (4) the right to enforce the payment of principal and interest; (5) participation in management; (6) a status equal to or inferior to that of regular corporate creditors; (7) the intent of the parties; (8) "thin" or adequate capitalization; (9) identity of interest between creditor and stockholder; (10) payment of interest only out of "dividend" money; and (11) the ability of the corporation to obtain loans from outside lending institutions.

Id. (citing A.R. Lantz Co. v. United States, 424 F.2d 1330, 1333 (9th Cir. 1970)).

84. See In re Lane, 742 F.2d 1311, 1314-15 (11th Cir. 1984) (noting the Eleventh and Fifth Circuits' use of a thirteen-factor test to analyze debt versus equity treatment of a cash advance). The factors are:

(1) the names given to the certificates evidencing the indebtedness; (2) the presence or absence of a fixed maturity date; (3) the source of payments; (4) the right to enforce payment of principal and interest; (5) participation in management flowing as a result; (6) the status of the contribution in relation to regular corporate creditors; (7) the intent of the parties; (8) 'thin' or adequate capitalization; (9) identity of interest between creditor and stockholder; (10) source of interest payments; (11) the ability of the corporation to obtain loans from outside lending institutions; (12) the extent to which the advance was used to acquire capital assets; and (13) the failure of the debtor to repay on the due date or to seek a postponement. 
ten-factor test. ${ }^{85}$ In the aggregate, courts have looked to as many as thirty-eight factors to distinguish debt from equity, ${ }^{86}$ with no one factor as dispositive. ${ }^{87}$ Consequently, with the debt versus equity issue comes a "lack of clarity, certainty, and logic in the judicial analysis" a lack of certainty in tax planning and little guidance for corporations in structuring transactions. ${ }^{89}$ Indeed, the Fifth Circuit stated in Tyler $v$. Tomlinson: "[T] his field of the law continues to defy symmetry."

In Sun Properties, Inc. v. United States, ${ }^{91}$ with facts that arguably point to equity, the Fifth Circuit found that the sole shareholder of a corporation received valid debt in exchange for a warehouse. ${ }^{92}$ The facts supporting equity characterization were: the purported loan amount of $\$ 125,000$ was not secured by a mortgage; the purported debt agreement did not provide for interest, but rather provided for the $\$ 125,000$ to be paid off at $\$ 4,000$ semiannually; and the corporation had nominal assets other than the warehouse, indicating it would not have liquidity to pay principal payments. ${ }^{93}$

In Farley Realty Corp. v. Commissioner, ${ }^{94}$ the Second Circuit

Id. (quoting Estate of Mixon v. United States, 464 F.2d 394, 402 (5th Cir. 1972)).

85. See J.S. Biritz Constr. Co. v. Comm'r, 387 F.2d 451, 457 (8th Cir. 1967) (using a tenfactor test to analyze debt versus equity treatment of a cash advance). The factors are:

(1) Whether the corporation is so grossly under-capitalized that the loans are in fact needed for capital purposes and are actually intended to be risked capital rather than a loan.... (2) Whether the purported loans were made in proportion to equity holdings.... (3) Whether the repayment of the loan was predicated on the success of the venture. (4) Whether there was a fixed date for payment of the note and a reasonable expectation of payment by that date. (5) Whether the note was subordinated to other corporate debts. (6) Whether third parties would have made the loan under the same conditions. (7) Whether the claimed loan was secured by a mortgage or otherwise. (8) Whether a provision was made for a sinking fund to retire the loan... (9) Whether the person making the purported loan participated in the management of the corporation.... [And] (10) [w] hether the corporation had a large proportion of debt to equity.

Id. (citations omitted).

86. Robert S. Holzman, The Interest-Dividend Guidelines, 47 TAXES 4, 4 (1969).

87. See John Kelley Co. v. Comm'r, 326 U.S. 521, 530 (1946) ("There is no one characteristic, not even exclusion from management, which can be said to be decisive in the determination of whether the obligations are risk investments in the corporations or debts."). See also Elec. Modules Corp. v. United States, 695 F.2d 1367, 1372 (Fed. Cir. 1982) ("[T] here is no single factor that is decisive on the issue."); L. Howard Adams, What Role for Equity in Applying Factors for Distinguishing Debt?, 138 TAX NOTES 1095 (2013) ("Not even a majority of the factors pointing in the desired direction is needed, because the debt-equity factors are not equally weighted.").

88. Gibson, supra note 7, at 454 .

89. Id. at 465

90. Tyler v. Tomlinson, 414 F.2d 844, 847 (5th Cir. 1969).

91. Sun Props., Inc. v. United States, 220 F.2d 171 (5th Cir. 1955).

92. See id. at $175-76$.

93. See id. at 172.

94. Farley Realty Corp. v. Comm'r, 279 F.2d 701 (2d Cir. 1960). 
adopted the bifurcation approach ${ }^{95}$ that was later enacted by Congress in section 385 in $1989 .{ }^{96}$ Because the court determined that the shareholder's equity interest was "separable" from his debt interest, the court bifurcated the instrument for federal income tax purposes. ${ }^{97}$ Thus, when the corporation liquidated, the $\$ 50,000$ at issue represented the settlement of the right to share in the corporation's financial success, rather than payment of interest on a $\$ 70,000$ loan that had already been paid in full. ${ }^{98}$

Although case law lacks a consistent analysis of the debt versus equity factors, courts agree that "[a] payment for which a taxpayer seeks a deduction must have economic substance." "99 In other words, interest is only deductible when it results from a transaction that has a "purpose, substance or utility apart from [its] anticipated tax consequences." Accordingly, the substance-rather than the form-of a transaction controls its tax treatment. ${ }^{101}$ For instance, in Laidlaw Transportation, Inc. $v$. Commissioner ${ }^{102}$ the Tax Court gave less weight to the debt versus equity factors relating to the form of the transaction, showing that labels like "debt" or "indenture" used for a transaction may signify little when the substance of the transaction supports equity characterization. ${ }^{103}$ In Ramig v. Commissioner, ${ }^{104}$ the Tax Court held that cash advances were equity even though four factors pointed to equity investment and five factors pointed to debt. ${ }^{105}$ This holding shows that the debt versus equity inquiry is "no mere counting of factors." 106 Therefore, the various approaches of the circuit courts and the Tax Court indicate the lack of uniformity regarding the debt versus equity inquiry.

\footnotetext{
95. See id. at 704.

96. See supra note 70 and accompanying text.

97. See Farley, 279 F.2d at 704.

98. See id.

99. See Laidlaw Transp., Inc. v. Comm'r, 75 T.C.M. (CCH) 2598, 2616 (1998) (citing Gregory v. Helvering, 293 U.S. 465, 467 (1935); United States v. Wexler, 31 F.3d 117, 124 (3d Cir. 1994); Krumhorn v. Comm'r, 103 T.C. 29, 48 (1994)).

100. Wexler, 31 F.3d at 124 (quoting Goldstein v. Comm'r, 364 F.2d 734, 740 (2d Cir. 1966)).

101. Laidlaw, 75 T.C.M. (CCH) at 2616.

102. Id. at 2598 .

103. See id. at 2617, 2624.

104. Ramig v. Comm'r, 101 T.C.M. (CCH) 1695 (2011), aff'd, 496 F. App'x 756 (9th Cir. 2012).

105. Id. at 1700 .

106. Id. (citing Bauer v. Comm'r, 748 F.2d 1365, 1368 (9th Cir. 1984)).
} 


\section{Recent Cases on Debt versus Equity Characterization}

The Tax Court reported few debt versus equity cases from 2003 to 2009. ${ }^{107}$ However, reporting of debt versus equity cases has become more common since 2010, likely due to a combination of factors. ${ }^{108}$ These factors include the increase in IRS resources to work on debt versus equity cases, the notable growth in cross-border financing, and being a part of the "larger regulatory effort towards deleveraging the U.S. economy." 109 In 2012, three debt versus equity cases determined in the Tax Court show the high tax dollars at stake, as well as how the Tax Court has analyzed thin capitalization. ${ }^{110}$

First, in Hewlett-Packard Co. v. Commissioner,${ }^{111}$ the Tax Court held that the petitioner's investment in a foreign corporation should be treated as debt. ${ }^{112}$ Accordingly, the petitioner was unable to deduct a $\$ 15,569,004$ capital loss because capital losses result from investments in capital assets, not from debt. ${ }^{113}$ The Tax Court analyzed eleven factors to arrive at its holding. ${ }^{114}$ One of the factors was adequacy of capitalization. ${ }^{115}$ The court stated: "The purpose of examining the debtto-equity ratio in characterizing an advance is to determine whether a corporation is so thinly capitalized that it would be unable to repay an advance. Such an advance would be indicative of venture capital rather

107. See Greenaway \& Marion, supra note 24, at 93 n.147 ("The Tax Court reported six relatively small debt-equity cases in 2001. The Tax Court reported four debt-equity cases in 2002 . The court then averaged between only one or two reported debt-equity cases per year for the next seven years.") (citations omitted).

108. See id. at 93.

109. See id. at 93-94, 99 (noting that since 2008 "the Service has worked large debt-equity cases with fervor" and "outbound interest payments without a corresponding income inclusion may present a systemic threat to the U.S. corporate tax base").

110. See generally Reynolds, supra note 9 (discussing three Tax Court cases from 2012 in which the main issue was debt versus equity characterization).

111. Hewlett-Packard Co. v. Comm'r, 103 T.C.M. (CCH) 1736 (2012).

112. Id. at 1737,1753 .

113. See id. at $1753-54$.

114. Id. at 1747-48. Specifically, the factors are:

(1) the labels on the documents evidencing the alleged indebtedness; (2) the presence or absence of a maturity date; (3) the source of payments; (4) the right of the alleged lender to enforce payment; (5) participation in management; (6) a status equal to or inferior to that of regular corporate creditors; (7) the intent of the parties; (8) the adequacy of the (supposed) borrower's capitalization; (9) whether stockholders' advances to the corporation are in the same proportion as their equity ownership in the corporation; (10) the payment of interest out of only "dividend money"; and (11) the borrower's ability to obtain loans from outside lenders.

Id. at 1747 (citing A.R. Lantz Co. v. United States, 424 F.2d 1330, 1333 (9th Cir. 1970)).

115. Id. at 1752-53. 
than a loan."116 Determining this factor favored debt characterization, the court noted that the capital structure of the foreign subsidiary appeared sufficiently secure. ${ }^{11}$

Second, in NA General Partnership v. Commissioner, ${ }^{118}$ the Tax Court held that petitioner's $\$ 932$ million of interest payments made on intercompany loans were properly deductible because the cash advance should be characterized as debt. ${ }^{119}$ In this case, ScottishPower plc (ScottishPower) advanced almost $\$ 5$ billion to NA General Partnership (NAGP). ${ }^{120}$ The cash advanced was recorded with loan notes, which had specified maturity dates and allowed ScottishPower the right to enforce payment. ${ }^{121}$ The Tax Court analyzed eleven factors, many of which coincided with the factors in Hewlett-Packard. ${ }^{122}$

In analyzing the factor of thin capitalization, the Tax Court emphasized the importance of analyzing the debt-to-equity ratio in the context of the corporation's industry. ${ }^{123}$ "For example, companies with high levels of business risk, such as those in highly uncertain environments (e.g., high-tech) or in cyclical or volatile industries generally cannot bear the risk of significant leverage. The opposite is true generally for companies with low business risk (e.g., utilities)."124 In this case, NAGP's expert witness compared the debt-to-equity ratio of NAGP to the ratios of similarly situated utilities, which the court used to arrive at its holding. ${ }^{125}$ The expert witness also utilized the fair market value of NAGP's equity value to determine that NAGP had an adequate

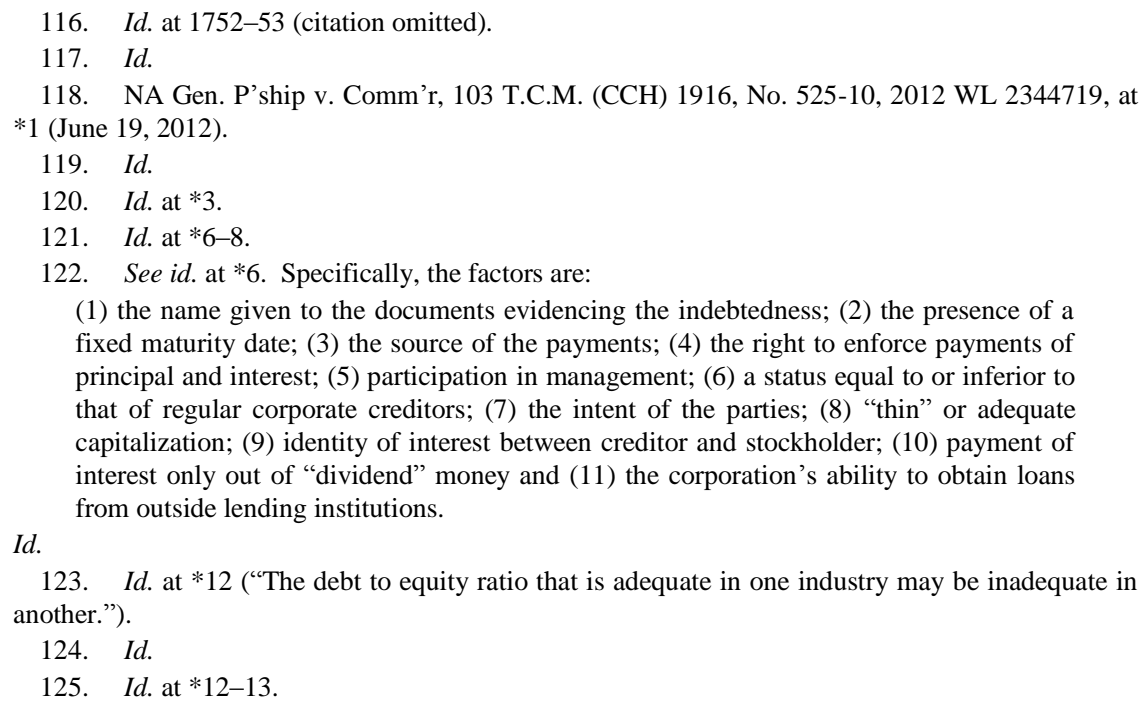
fixed maturity date; (3) the source of the payments; (4) the right to enforce payments of principal and interest; (5) participation in management; (6) a status equal to or inferior to that of regular corporate creditors; (7) the intent of the parties; (8) "thin" or adequate capitalization; (9) identity of interest between creditor and stockholder; (10) payment of interest only out of "dividend" money and (11) the corporation's ability to obtain loans 
capital structure to support debt characterization. ${ }^{126}$

Third, in PepsiCo Puerto Rico, Inc. v. Commissioner, ${ }^{127}$ the Tax Court held that advance agreements issued by foreign subsidiaries to domestic subsidiaries should be characterized as equity. ${ }^{128}$ The Tax Court analyzed thirteen factors to arrive at its holding. ${ }^{129}$ In determining the "thinness" of capital structure factor supported equity characterization, the court relied on the entity's debt-to-equity ratio according to industry standards. ${ }^{130}$ In addition, the court noted: "[P]erhaps most convincingly, ... a commercial bank or third party lender would not have engaged in transactions of comparable risk." 131 Similar to its analysis in NA General Partnership, the Tax Court emphasized the importance of industry standards in analyzing the debtto-equity ratio, as well as the importance of third party lenders. ${ }^{132}$

The common themes of these three cases show the types of cases on which the IRS, as well as the Tax Court, currently focus. ${ }^{133}$ First, these cases portray the large dollars at stake for corporations regarding the debt versus equity characterization of a cash advance. ${ }^{134}$ Second, these cases support the importance of analyzing the debt-to-equity ratio in the context of the subsidiary's industry. ${ }^{135}$ Finally, these cases exhibit that taxing authorities are increasingly scrutinizing cross-border intercompany financing arrangements. ${ }^{136}$

\footnotetext{
126. Id.

127. PepsiCo P.R., Inc. v. Comm'r, 104 T.C.M. (CCH) 322 (2012).

128. Id. at 322,345 .

129. Id. at 335. Specifically, the factors are:

(1) names or labels given to the instruments; (2) presence or absence of a fixed maturity date; (3) source of payments; (4) right to enforce payments; (5) participation in management as a result of the advances; (6) status of the advances in relation to regular corporate creditors; (7) intent of the parties; (8) identity of interest between creditor and stockholder; (9) "thinness" of capital structure in relation to debt; (10) ability of the corporation to obtain credit from outside sources; (11) use to which advances were put; (12) failure of debtor to repay; and (13) risk involved in making advances.

Id. (citing Dixie Dairies Corp. v. Comm'r, 74 T.C. 476, 493 (1980)).

130. Id. at 343-44.

131. Id. at 345

132. See id. at 343-44.

133. See Reynolds, supra note 9 (noting that, following the release of these three opinions, an IRS Special Counsel stated that "when the primary purpose of a transaction is to get to a tax answer ... that does affect the analysis"). These three cases may indicate an overall trend of the IRS's success against taxpayers that entered into transactions lacking a valid business purpose.

134. See supra note 110 and accompanying text.

135. See supra notes 123 and 132 and accompanying text.

136. Philip Antoon, Intercompany Debt-How Much is Reasonable?, ALVAREZ \& MARSAL (Aug. 6, 2013), http://www.alvarezandmarsal.com/intercompany-debt-\%E2\%80\%94-how-muchreasonable- 0 .
} 


\section{Case Law Supporting Thin Capitalization as a Principal Factor}

Although this field of law may defy symmetry, the ultimate issue in the debt versus equity distinction lies in objective tests of economic reality. ${ }^{137}$ The touchstone of economic reality is "whether the transaction would have taken the same form had it been between the corporation and an outside lender."138 In the context of debt versus equity classification, an economic reality test asks whether the "funds were advanced with the reasonable expectation of repayment regardless of the success of the business." 139

Here, the debt-to-equity ratio is the most commonly used criterion to analyze economic reality. ${ }^{140}$ For instance, an outside creditor is more willing to extend funds if a corporation has a low debt-to-equity ratio, which is associated with more assets available to support loans. ${ }^{141}$ In other words, a creditor is likely more secure if there is a "cushion" in shareholders' equity. ${ }^{142}$ In addition to analyzing economic reality, the ratio is also the most objective way to determine if a corporation is thinly capitalized. $^{143}$ Therefore, thin capitalization has remained a principal factor in judicial analysis over the past several decades. ${ }^{144}$

Courts have not determined a safe harbor that automatically would classify debt as a "sham merely because of a high debt-to-equity ratio." "145 Rather, courts look to the industry of the corporation to

137. See Scriptomatic, Inc. v. United States, 555 F.2d 364, 367 (3d Cir. 1977), aff'g 397 F Supp. 753 (E.D. Pa. 1975) (asserting that in debt versus equity cases "the ultimate issue is measurement of the transaction by objective tests of economic reality"). See also Litton Bus. Sys., Inc. v. Comm'r, 61 T.C. 367, 377 (1973) (stating that in debt versus equity cases the ultimate question is: "Was there a genuine intention to create a debt, with a reasonable expectation of repayment, and did that intention comport with the economic reality of creating a debtor-creditor relationship?").

138. See Scriptomatic, 555 F.2d at 367.

139. Becker, supra note 28, at 221.

140. See Scriptomatic, Inc. v. United States, 397 F. Supp. 753, 762 (E.D. Pa. 1975).

141. See Gibson, supra note 7, at 480 ("The creditor's position is more secure if there exists a cushion at the shareholder equity level. Presumably, an outside creditor is more willing to extend credit if a corporation has a low debt-to-equity ratio, as there are more assets available to support additional loans.").

142. Id.

143. See Becker, supra note 28 , at 228 (asserting that a debt-to-equity ratio test is based upon "more objective and verifiable criteria").

144. See id. at 221 (stating that the adequacy of capitalization of the corporation is a "significant, but not conclusive, factor in distinguishing stock from debt"). See also Gibson, supra note 7, at 480 ("[T]hin capitalization remains an important element in the judicial analysis of the debt/equity distinction.").

145. Leach Corp. v. Comm'r, 30 T.C. 563, 578 (1958). See also Jim McEvoy, Canada: U.S. Federal Rules Applicable to Loans from a Canadian Parent to a U.S. Subsidiary, COLLINS BARROW 
determine the reasonableness of the debt-to-equity ratio. ${ }^{146}$ Expert testimony is considered to determine whether a corporation is adequately capitalized according to the standards of the corporation's industry. ${ }^{147}$ As a result, the amount of equity capital that would be inadequate in one industry may be sufficient by standards of another industry. ${ }^{148}$

Courts have also considered the prospect of future earnings, which may justify a high debt-to-equity ratio and result in debt characterization. ${ }^{149}$ While the Treasury proposed regulations in 1980 for both the outside and inside debt-to-equity ratios, ${ }^{150}$ the Tenth Circuit held that the relevant ratio is the outside ratio, which compares the corporation's total liabilities to shareholders' equity. ${ }^{151}$ The Tenth Circuit's rationale was that the outside ratio "is the ratio a prospective creditor would have considered when deciding whether to advance funds." 152

Several cases have noted the importance of the debt-to-equity ratio to the analysis. ${ }^{153}$ In Laidlaw Transportation, Inc. v. Commissioner, ${ }^{154}$ the Tax Court defined a cash advance as equity if "(a) the debt to equity ratio was initially high, (b) the parties realized that [the ratio] would likely go

2 (May 2014), http://www.collinsbarrow.com/uploads/docs/newsletter/national/taxation/2014/us-taxalert-may-2014.pdf (asserting that the IRS will respect debt characterization if the corporation's debt-to-equity ratio does not exceed 3 to 1); HARRY G. HENN \& JOHN R. AleXANDER, LAwS OF CORPORATIONS AND Other BUSINESS ENTERPRises 416 n.15 (West Publ'g Co., 3d ed. 1983) (asserting that a debt-to-equity ratio of 4 to 1 should be a rule of thumb to guarantee debt treatment).

146. See Scotland Mills, Inc. v. Comm'r, 24 T.C.M. (CCH) 265, 273 (1965) ("What amounts to adequate capitalization varies according to the industry and within the industry according to the type of operation planned."). See also Sigmon v. Comm'r, 55 T.C.M. (CCH) 1567, 1584-85 (1988) (analyzing thin capitalization in light of the economic realities of petitioner's integrated coal business).

147. See Scotland Mills, 24 T.C.M. $(\mathrm{CCH})$ at 273 (stating that courts "must give consideration to expert testimony as to whether a given company is adequately capitalized by the standards of the industry").

148. See Steven Kaplan \& Guillaume Lefebvre, CAT Bonds: Tax Treatment of an Innovative Financial Product, 16 J. TAX'N F. InstiTuTIONS 5, 11 (2003) (“Courts have recognized that industry practices may justify any ratio, even though an amount of equity capital that would be inadequate to launch a corporation in one industry may be quite sufficient by the standards of another . ...").

149. See Baker Commodities, Inc. v. Comm'r, 48 T.C. 374, 396-98 (1967), aff'd, 415 F.2d 519 (9th Cir. 1969) (holding that a debt-to-equity ratio of almost 700 to 1 was not unrealistic, resulting in bona fide indebtedness, given the corporation's financial success in the four years subsequent to the note's issuance).

150. See supra note 61 and accompanying text.

151. Jensen v. Comm'r, No. 98-9021, 2000 WL 300208, at *4 (10th Cir. Mar. 23, 2000).

152. Id.

153. See, e.g., Kraft Foods Co. v. Comm'r, 232 F.2d 118, 127 (2d Cir. 1956) (“[T]he debtequity ratio resulting from a transaction is of great importance in determining whether an ambiguous instrument is a debt or an equity interest ....”).

154. Laidlaw Transp., Inc. v. Comm'r, 75 T.C.M. (CCH) 2598 (1998). 
higher, and (c) the recipient of the funds used a substantial part of the funds to buy capital assets and to meet expenses needed to begin operations." ${ }^{155}$ Additionally, in Bauer v. Commissioner, ${ }^{156}$ the Ninth Circuit examined the debt-to-equity ratio "to determine whether a corporation is so thinly capitalized that a business loss would result in an inability to repay the advance; such an advance would be indicative of venture capital rather than a loan." 157 The court was "concerned with the degree of risk the loan presents to the lender and whether an independent lender, such as a bank, would be willing to make the loan." "158 Therefore, one of the common factors among the circuits' lists of factors, as well as the factors listed in section 385 and Notice 94-47, is the "thinness" of the capital structure of the corporation, determined by the debt-to-equity ratio. $^{159}$

\section{ANALYSIS}

The courts' application of the debt versus equity factors as a whole makes clear that thin capitalization is a principal factor. Therefore, the Treasury should propose regulations under section 385 to establish thin capitalization as a principal factor in the analysis. The regulations should also define the inputs - namely, total indebtedness and total assets minus total indebtedness - into the calculation of the debt-to-equity ratio. Such regulations would have the beneficial effects of decreasing litigation, fulfilling congressional intent, increasing predictability and consistency, and incentivizing corporations to decrease debt.

\section{A. Other Debt Versus Equity Factors}

Before turning to a specific discussion of thin capitalization, however, a brief critique of several other factors listed in case law, section 385, and Notice $94-47$ is necessary. Several of the factors have been discounted or considered irrelevant in particular cases, showing that the factors - derived from case law from the mid-1900s - are no longer relevant in the current financial market. These factors include participation in management, subordination, intent of the parties, sinking fund or source of payments, and use of cash advance to purchase capital

155. Id. at 2620 .

156. Bauer v. Comm'r, 748 F.2d 1365 (9th Cir. 1984).

157. Id. at 1369 (citing Gilbert v. Comm'r, 248 F.2d 399, 407 (2d Cir. 1957)).

158. Id.

159. See supra notes $59,75,82-85$ and accompanying text. 
assets.

\section{Participation in Management}

One of the factors listed in Notice 94-47 and analyzed in several cases is "whether the instruments give the holders the right to participate in the management of the issuer." 160 If a purported creditor has an increased right to participate in management of the issuer because of the cash advance, then the purported creditor participates as a shareholder rather than as a bona fide creditor. ${ }^{161}$ Thus, the IRS would likely argue that the purported debt should be characterized as equity. ${ }^{162}$

As the Third Circuit noted, however, it may be common for creditors to sit on a corporation's board of directors, particularly when the corporation has financial problems. ${ }^{163}$ Similarly, the Tax Court noted that creditors' participation in management may be "necessary for compliance with State law on securities registration." 164 Because a lender's participation in management may be required in some jurisdictions, this factor should not hold much weight in the debt versus equity analysis. The Tax Court recognizes this observation and has conceded that this factor is neutral in cases in which a parent advances cash to a subsidiary. ${ }^{165}$ Therefore, participation in management is of little value in the debt versus equity analysis.

\section{Subordination}

Case law, section 385, and Notice 94-47 also refer to subordination, which considers "whether the rights of the holders of the instruments are subordinate to rights of general creditors." 166 Accordingly, if the holders of the instruments have rights subordinate to the rights of general creditors, then this suggests the cash advance should be characterized as equity. ${ }^{167}$ The Tax Court has observed, however, that subordination has

\footnotetext{
160. I.R.S. Notice 94-47, 1994-1 C.B. 357.

161. See Estate of Mixon v. United States, 464 F.2d 394, 406 (5th Cir. 1972).

162. See id.

163. Cohen v. KB Mezzanine Fund II, LP (In re SubMicron Sys. Corp.), 432 F.3d 448, 457-58 (3d Cir. 2006) ("[]]t is 'not unusual for lenders to have designees on a company's board, particularly when the company [is] a distressed one."') (quoting In re SubMicron Sys. Corp., 291 B.R. 314, 32526 (D. Del. 2003))

164. Green Bay Structural Steel, Inc. v. Comm'r, 53 T.C. 451, 456 (1969).

165. See Am. Offshore, Inc. v. Comm'r, 97 T.C. 579, 603 (1991).

166. I.R.S. Notice 94-47, 1994-1 C.B. 357.

167. See Estate of Mixon v. United States, 464 F.2d 394, 406 (5th Cir. 1972).
} 
become "increasingly common in the business world" and should not preclude the cash advances from constituting bona fide indebtedness. ${ }^{168}$ In Green Bay Structural Steel, Inc. v. Commissioner, ${ }^{169}$ the Tax Court took a step further by treating subordination as an "approved business practice," rather than treating the note holders as preferred shareholders. ${ }^{170}$ Thus, subordination holds little weight in the debt versus equity analysis.

\section{Intent of the Parties}

The intent of the parties is also a factor considered when determining debt versus equity characterization. ${ }^{171}$ In other words, did the parties intend for the financial instrument to be treated as debt or equity? However, as the Fifth Circuit observed, the problem here is that "courts look to intent only when other relevant, objective factors regarding the transaction fail to clearly indicate either debt or equity." ${ }^{172}$ As discussed above, ${ }^{173}$ in Laidlaw Transportation, Inc. v. Commissioner, ${ }^{174}$ the Tax Court noted that if the parties indicate their intent by labeling a document as debt when in substance it is equity, the intent of the parties holds little, if any, weight. ${ }^{175}$ Accordingly, the intent of the parties holds minimal weight in the debt versus equity analysis.

\section{Sinking Fund or Source of Payments}

Not mentioned in section 385 or Notice $94-47,{ }^{176}$ the two factors of sinking fund and source of payments are duplicative because a sinking fund is an account reserved specifically for repayment of debt. ${ }^{177}$ Courts have held that if a sinking fund is a source of interest and principal payments, courts are more likely to assign debt characterization to the

\footnotetext{
168. Estate of Hosmer v. Comm'r, 32 T.C.M. (CCH) 77, 82 (1973).

169. Green Bay, 53 T.C. at 451.

170. Id. at 457 (quoting United States v. Snyder Bros. Co., 367 F.2d 980, 989 (5th Cir. 1966) (Gewin, J., dissenting)). See also Greenaway \& Marion, supra note 24, at 87 ("Subordination is an accepted business practice.").

171. See I.R.S. Notice 94-47, 1994-1 C.B. 357 (listing a factor of "whether the instruments are intended to be treated as debt or equity for non-tax purposes").

172. Tex. Farm Bureau v. United States, 732 F.2d 437, 438 (5th Cir. 1984) (citing Estate of Mixon, 464 F.2d at 407-08; Tyler v. Tomlinson, 414 F.2d 844 (5th Cir. 1969)).

173. See supra text accompanying notes 101-03.

174. Laidlaw Transp., Inc. v. Comm'r, 75 T.C.M. (CCH) 2598 (1998).

175. See id. at $2617,2624$.

176. See supra notes 59 and 73-75 and accompanying text.

177. See Green Bay Structural Steel, Inc. v. Comm'r, 53 T.C. 451, 455 (1969).
} 
cash advance from the parent to the subsidiary corporation. ${ }^{178}$ Alternatively, if there is not a sinking fund and the source of interest payments is earnings of the borrowing corporation, courts are more likely to characterize the cash advance as equity because repayment of the cash advance looks like a dividend. ${ }^{179}$

The Tax Court has supported debt characterization and found nothing objectionable about payment of interest through earnings when projected earnings are substantial and adequate assets act as a reserve. ${ }^{180}$ Similarly, the Tax Court has discounted this factor by holding debt characterization where financial projections provided reasonable justification to expect repayment of both accrued interest and the principal amount of advances. ${ }^{181}$ As a result, debt characterization may result notwithstanding the source of repayments of interest or principal. ${ }^{182}$ Therefore, these factors are of little value in the debt versus equity analysis.

\section{Use of Cash Advance to Purchase Capital Assets}

Some courts, in determining whether a cash advance is debt or equity, have considered whether the borrowing corporation used cash advances to purchase capital assets. ${ }^{183}$ Similar to the sinking fund and source of payments factors, this factor is not listed in either section 385 or Notice 94-47. ${ }^{184}$ Yet, several court opinions have looked to this factor to characterize a cash advance as equity. In Scriptomatic, Inc. v. United States, ${ }^{185}$ the U.S. District Court for the Eastern District of Pennsylvania disregarded this factor, asserting:

First, to require, as a rule of law, that to avoid certain tax consequences a company must acquire its core assets solely with capital funds is unrealistic and unfair. It is not necessary that essential properties be acquired by paid in equity for a company to have a sound financial structure. In fact, it may be detrimental to tie up its total capital in that

\footnotetext{
178. See id. at 458.

179. See id.

180. Id.

181. Racal Elecs., Inc. v. Comm'r, 60 T.C.M. (CCH) 756, 767-68 (1990).

182. Greenaway \& Marion, supra note 24 , at 85.

183. See, e.g., Roth Steel Tube Co. v. Comm'r, 800 F.2d 625, 630 (6th Cir. 1986) (including within an eleven-factor test a factor for "the extent to which the advances were used to acquire capital assets") (citing Raymond v. United States, 511 F.2d 185, 190-91 (6th Cir. 1975))).

184. See supra notes 59 and $73-75$ and accompanying text.

185. Scriptomatic, Inc. v. United States, 397 F. Supp. 753 (E.D. Pa. 1975), aff'd, 555 F.2d 364 (3d Cir. 1977).
} 
way. It is common business practice to obtain financing to buy core assets from many different sources. ${ }^{186}$

The district court pointed out that businesses often use third party debt, rather than shareholders' equity, to purchase capital assets. ${ }^{187}$ Other courts have concurred because some courts simply ignore this factor. ${ }^{188}$ Consequently, this factor holds little weight in the debt versus equity analysis.

\section{B. Thin Capitalization as a Principal Debt Versus Equity Factor}

The numerous factors used by the courts to analyze the debt versus equity issue can "easily [be] manipulated and no one factor alone is determinative." 189 As such, "reliance on more objective types of evidence is generally desirable" to resolve debt versus equity controversies. $^{190}$ The debt-to-equity ratio offers an objective evaluation of whether a cash advance is debt or equity for tax purposes, and the ratio serves as a strong indication of whether the corporation is thinly capitalized.

While several other factors in the debt versus equity analysis have proved of little value, thin capitalization remains a principal factor. In John Kelley Co. v. Commissioner,${ }^{191}$ the Supreme Court of the United States established the importance of thin capitalization as the test for economic reality in passing dictum: "As material amounts of capital were invested in stock, we need not consider the effect of extreme situations such as nominal stock investments and an obviously excessive debt structure."192 Thin capitalization, determined from the debt-to-equity ratio, is an important factor to which a third party commercial lender would look. ${ }^{193}$

An empirical analysis of 126 debt versus equity cases decided between 1954 and 1987 revealed that the debt-to-equity ratio is a

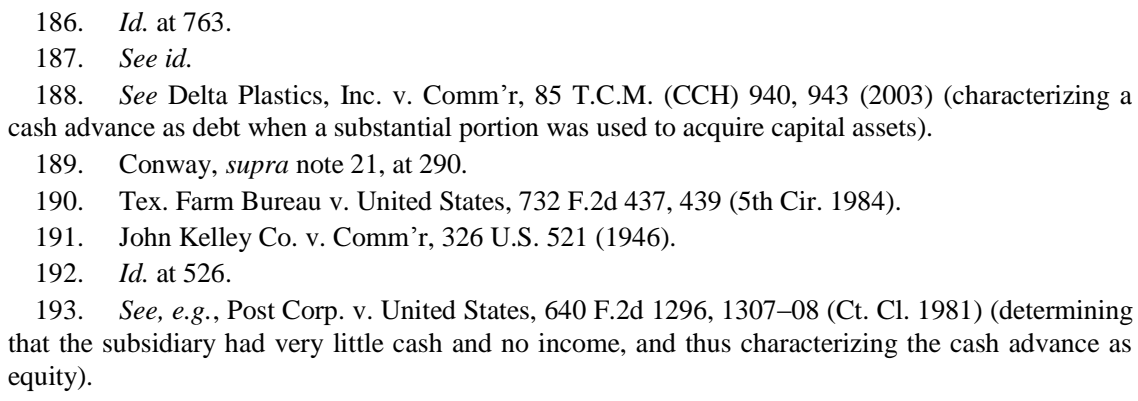


principal factor. ${ }^{194}$ Performed by three experts in tax law, the study found the seven "most discriminative" factors: (1) enforcement of creditor's rights; (2) debt-to-equity ratio; (3) creditworthiness of borrower; (4) formal documentation; (5) use of corporate profits as the source of repayment; (6) subordination; and (7) sinking fund. ${ }^{195}$ While the debt-to-equity ratio is not at the top of the list, it is noteworthy that the creditworthiness of the borrower - often determined by use of the debt-to-equity ratio-is among these factors. Because these factors appear duplicative, this observation indicates their combined importance to the debt versus equity analysis.

Analysis by other commentators supports the assertion that thin capitalization is a principal factor of the debt versus equity analysis. Two commentators of KPMG LLP classified the debt versus equity factors into four categories: useful, malleable, neutral, and deadwood. ${ }^{196}$ The useful category included: (1) "Intent of the parties"; (2) "Thinness of capital structure"; (3) "Credit risk"; and (4) "Source of 'interest' payments."197 Similar to the empirical analysis published in 1990, Greenaway and Marion rank thin capitalization and credit risk, or creditworthiness, among the top useful factors in the debt versus equity analysis. ${ }^{198}$

In a similar way, another commentator proposed a direct approach to the debt versus equity classification by using the "availability of thirdparty loans" as the principal test to apply to shareholder loans in closely held corporations. ${ }^{199}$ Focusing primarily on this factor supports the assertion that the "thinness" of capital structure is a major factor because in order to obtain a third-party loan, an entity must not be "thinly" capitalized and must have a comparatively advantageous debt-to-equity ratio.

In contrast, other commentators assert that the factor of the issuer's capitalization should be disregarded altogether from the analysis in

194. See Paul J. Robertson, Zoel Daughtrey, \& Daryl V. Burckel, Debt or Equity? An Empirical Analysis of Tax Court Classification During the Period 1955-1987, 47 TAX NoTES 707 (1990).

195. Id. at 711-17.

196. Greenaway \& Marion, supra note 24 , at $81,92$.

197. Id. at 92. Unhelpful because they are within a taxpayer's control, malleable factors included: (1) "Name of instrument"; (2) "Right to enforce payments"; (3) "Presence of maturity date"; and (4) "Repayment history." Id. Adding little to the analysis when viewed in isolation, neutral factors included: (1) "Identity of interest"; (2) "Subordination"; and (3) "Participation in management." Id. Considered archaic, deadwood factors included: (1) "Source of repayment" and (2) "Use of advances." Id.

198. See id. at 88, 90-91.

199. Wayne M. Gazur, An Arm's Length Solution to the Shareholder Loan Tax Puzzle, 40 SETON Hall L. REV. 407, 418 (2010). 
nearly all circumstances because "[a] corporation should be free to choose its own best mix of debt and equity without concern that the Service or courts will subsequently reclassify some of its debt as equity for tax purposes." 200 Furthermore, "[t]he average debt ratio of some very successful corporations in Japan would fail almost all of the tests advanced in the past by courts and the Treasury."201 Although these observations may be true, the issuer's capital structure is a main factor that a lending institution, such as a bank or credit union, would consider when deciding whether to extend credit to a debtor. ${ }^{202}$ The debt-toequity ratio is "often used by lenders to determine whether an enterprise can obtain additional future financing ... [and] whether that enterprise is in compliance with debt covenants under existing obligations."203 While a corporation should be free to choose its own debt-equity mix, if the corporation has a very high debt-to-equity ratio that would cause a thirdparty creditor to not lend funds, the corporation should not be entitled to debt characterization - and associated interest deductions-for U.S. federal income tax purposes. Therefore, thin capitalization proves a principal factor in the debt versus equity analysis.

\section{Proposal to Solve the Debacle}

Case law has demonstrated that thin capitalization is a principal factor in the debt versus equity analysis. ${ }^{204}$ Yet, there is a general lack of guidance for the corporate taxpayer regarding thin capitalization. ${ }^{205}$ Therefore, the Treasury should provide guidance to improve the tax system, ${ }^{206}$ increase predictability for taxpayers and consistency across the courts, and decrease litigation. ${ }^{207}$ Although some commentators believe

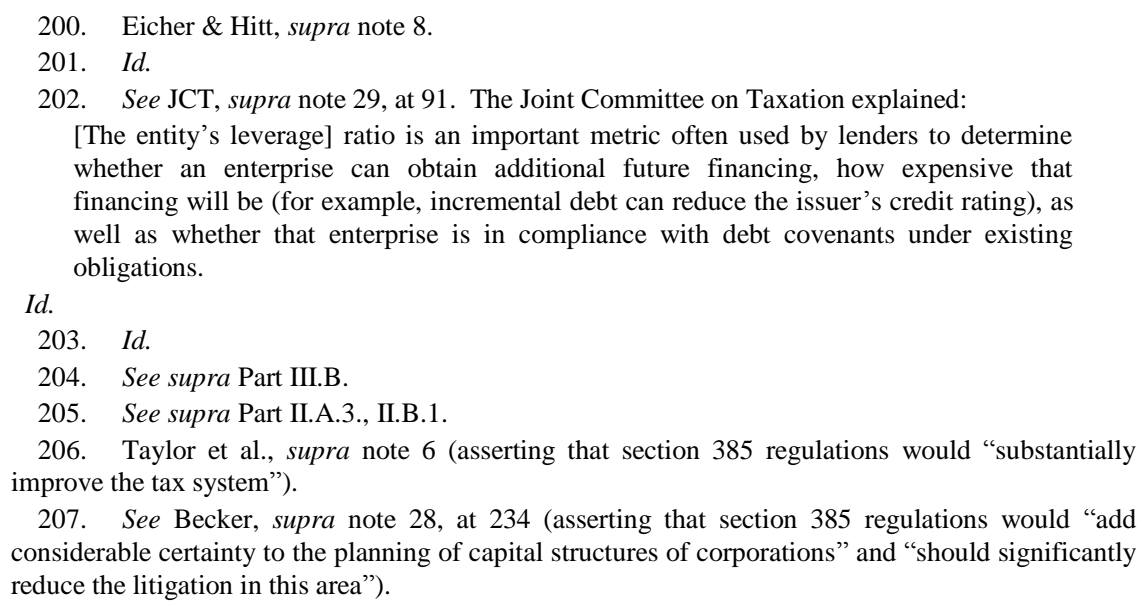

207. See Becker, supra note 28, at 234 (asserting that section 385 regulations would "add considerable certainty to the planning of capital structures of corporations" and "should significantly reduce the litigation in this area"). 
that debt versus equity issues should be determined solely under case law, ${ }^{208}$ Congress intended the Treasury to provide guidance through section 385 regulations for corporate taxpayers. ${ }^{209}$

Specifically, under section $385(\mathrm{a})$, the Secretary of the Treasury should prescribe the "necessary or appropriate" ${ }^{210}$ regulations to provide more guidance on thin capitalization. As discussed above, ${ }^{211}$ the proposed regulations should establish the "thinness" of capital structure, and associated debt-to-equity ratio calculation, ${ }^{212}$ as a principal factor for debt versus equity characterization. The term principal factor means that the proposed regulations should specify that thin capitalization is not a dispositive factor in the analysis (i.e. as a single factor in the analysis, it is not determinative of debt or equity characterization); however, the factor of thin capitalization must be considered in determining whether a cash advance is debt or equity. ${ }^{213}$ The proposed regulations should not dictate an objective safe harbor debt-to-equity ratio because of differing business models across industries. ${ }^{214}$ Furthermore, the proposed regulations should specify that the fair market values of debt and equity — rather than adjusted tax basis or book value — must be used for inputs of the ratio. ${ }^{215}$

208. Taylor et al., supra note 6 (including commentary from Sol Coffino, President of Tax Executives Institute, Inc., who felt that debt-equity issues should be resolved under case law, at the time of the withdrawal of the proposed regulations in 1983).

209. Id. In 1983, Robert H. Aland of the Chicago office of Baker \& McKenzie stated:

$[T]$ he withdrawal of the final and proposed regulations under section 385 , including the hybrid instrument provisions, constitutes a serious error on the part of the Service, since it frustrates the congressional purpose in 1969 for enacting section 385, which was to provide (primarily through regulations) guidance for taxpayers in distinguishing debt from equity for federal income tax purposes.

Id.

210. I.R.C. § 385(a) (2012).

211. See supra Part III.B.

212. The proposed regulations should also establish the debt-to-equity ratio calculation to take place at the end of the taxable year, consistent with section 163(j). See I.R.C. § 163(j)(2)(A)(ii) (asserting the applicable ratio of debt to equity is "as of the close of such taxable year").

213. Treasury regulations use the term principal factor in other contexts. For example, a Treasury regulation under $\S 2032 \mathrm{~A}$ regarding material participation in farm or other business operations states: "No single factor is determinative of the presence of material participation, but physical work and participation in management decisions are the principal factors to be considered." Treas. Reg. § 20.2032A-3(e)(2) (as amended in 1981). Additionally, in determining whether income or capital gain is "effectively connected for the taxable year with the conduct of a trade or business in the United States," the principal factors to be applied are the asset-use test and the businessactivities test. Treas. Reg. § 1.864-4 (as amended in 2005).

214. See infra Part III.C.1.

215. See infra Part III.C.2. The proposed regulations should contain the following crucial language regarding fair market value:

The debt-to-equity ratio of a corporation is the ratio that (i) the fair market value of the 


\section{No Objective Safe Harbor Debt-to-Equity Ratio}

Regarding a safe harbor debt-to-equity ratio, in Post Corp. v. United States, ${ }^{216}$ the Court of Claims observed: "[C]ourts have uniformly rejected any fixed ratio of debt to equity as a per se test of tax avoidance, recognizing instead that corporations in various industries and in different stages of development have legitimate needs for varying debt structures ...."217 The Court of Claims' observation is unequivocally true because courts have ruled across the entire spectrum in regards to debt-to-equity ratios. ${ }^{218}$ Courts have found debt characterization where the corporation's debt-to-equity ratios were 17 to $1,{ }^{219} 310$ to $1,{ }^{220}$ and 692.5 to $1 .{ }^{221}$ In addition, the Tax Court found equity characterization where the corporation's debt-to-equity ratio was 166 to $1^{222}$ and 9.5 to $1^{223}$ These irreconcilable figures provide further support that the regulations should not provide for a safe harbor debt-to-equity ratio. Rather, the focus should be on the economic reality and industry of the corporation.

The Tax Court exemplified this approach in Delta Plastics, Inc. v. Commissioner. ${ }^{224}$ Holding that the cash advance was debt, ${ }^{225}$ the court stated:

corporation's liabilities, bears to (ii) the corporation's stockholders' equity. The stockholders' equity in a corporation is the excess of (i) the fair market value of its assets, over (ii) the fair market value of its liabilities. Fair market value is the price at which an asset or liability would change hands between a willing buyer and a willing seller, neither being under any compulsion to buy or to sell and both having reasonable knowledge of all relevant facts.

The language in these definitions is modeled off of Proposed Regulation $§ 1.385-3(b)-(c)$. See Prop. Treas. Reg. § 1.385-3(b)-(c), 45 Fed. Reg. 18,957, 18,964 (Mar. 24, 1980).

216. Post Corp. v. United States, 640 F.2d 1296 (Ct. Cl. 1981).

217. Id. at 1307.

218. See infra notes $219-23$ and accompanying text.

219. Adams v. Comm'r, 58 T.C. 41, 53-54, 57 (1972).

220. Sun Props., Inc. v. United States, 220 F.2d 171, 175 (5th Cir. 1955).

221. Baker Commodities, Inc. v. Comm'r, 48 T.C. 374, 396 n.20, 401 (1967), aff'd, 415 F.2d 519 (9th Cir. 1969).

222. Fries v. Comm'r, 73 T.C.M. (CCH) 2085, 2086, 2089-90 (1997).

223. Sigmon v. Comm'r, 55 T.C.M. (CCH) 1567, 1584, 1586 (1988). Here, the court stated:

[The debt-to-equity ratio of 9.5 to 1 ] indicates that the companies as a group were thinly capitalized. The large deficits in retained earnings and negative owners' equity for most of these companies also supports our finding that the integrated coal business operated by Sigmon was thinly capitalized. This factor further supports our conclusion that this advance represented a contribution to capital.

Id. at 1584 .

224. Delta Plastics, Inc. v. Comm'r, 85 T.C.M. (CCH) 940 (2003).

225. Id. at 944 . 
In spite of petitioner's initial debt-to-equity ratio of $26: 1$, prior to startup of petitioner, petitioner's officers and directors understood petitioner's business and the plastics manufacturing industry and reasonably projected that petitioner would be successful. As a result of revenues quickly generated by its operations, petitioner's debt-to-equity ratio was reduced in just over 3 years to $4: 1$. This reduction indicates to us, in this case, that petitioner was adequately capitalized from its inception.

In this case, if the Tax Court had applied a safe harbor debt-to-equity ratio of 10 to $1,{ }^{227}$ then the 26 to 1 ratio would have failed the safe harbor test from the outset. Thus, the result would have been that the cash advance was equity, not debt. However, the Tax Court looked to the economic reality of the capital structure and to the financial situation of the corporation to arrive at its holding. ${ }^{228}$

While lack of an objective safe harbor may provide no definite criteria for corporations to judge whether a court will consider its capital structure inadequate, ${ }^{229}$ the flexibility of debt-to-equity ratios across industries trumps the safe harbor approach. ${ }^{230}$ While companies may typically issue debt with a debt-to-equity ratio of approximately 3 to 1 , there may be industries in which a supportable debt-to-equity ratio is above or below this level. ${ }^{231}$ For example, a reasonable debt-to-equity in the insurance industry may be unreasonable in other industries. Therefore, the proposed regulations should not dictate a safe harbor debtto-equity ratio.

\section{Fair Market Values for the Debt-to-Equity Ratio}

Because the debt-to-equity ratio is critical to the debt versus equity

226. Id. at 943.

227. The proposed regulations from 1982 provided a safe harbor ratio of 10 to 1 . See Prop. Treas. Reg. § 1.385-6(g)(3)(i), 47 Fed. Reg. 164, 182 (Jan. 5, 1982).

228. See Delta Plastics, Inc., 85 T.C.M. (CCH) at 943-44.

229. See Gibson, supra note 7, at 482 ("[D]espite the potential benefits of flexibility, the amalgamation of ratios deemed acceptable and unacceptable by various courts provides no definite criteria for corporations to judge whether a court will consider its capital structure inadequate."); Eicher \& Hitt, supra note 8 ("[A] safe harbor is still necessary so that taxpayers can structure financing transactions without fear of subjective interpretation of the rules by courts and the Service."). See also Gibson, supra note 7, at 482 ("In order to provide more certainty to the corporate community, the Congress, Treasury Department, or the courts should develop safe harbor rules, expressly indicating what ratios presumptively will be considered adequate.").

230. For instance, the IRS considers the importance of industry norms by referring to them in the fact pattern of Revenue Ruling 85-119: "HC is not thinly capitalized. Whether the Notes constitute debt or equity, after their issuance $\mathrm{HC}$ will have a debt-equity ratio that is within the industry norm." Rev. Rul. 85-119, 1985-2 C.B. 60.

231. Antoon, supra note 136. 
analysis, the proposed regulations should address the calculation of the debt-to-equity ratio. Over the decades of litigation in this area, courts have not agreed upon standards or a mathematical formula for the debtto-equity ratio. ${ }^{232}$ Some commentators posit that this lack of agreement suggests that the ratio is "rarely decisive despite the effort practitioners and the Service tend to put into the calculations." 233 However, this argument loses sight of the main purpose of looking to the debt-to-equity ratio, which is to evaluate the economic reality of the corporation's capitalization structure. If a prospective borrower is thinly capitalized, a lender will not expect to be repaid, and thus will likely not advance funds to the prospective borrower. ${ }^{234}$

While case law proves ambiguous regarding the calculation of the debt-to-equity ratio, legislative history for section 385 indicates that Congress intended that " $[t]$ he debt-equity ratio of the issuing corporation for purposes of this test generally is determined by comparing the corporation's total indebtedness with the excess of its money and other assets over that indebtedness."235 These inputs-total indebtedness and total equity (total assets minus total indebtedness) — can be valued at (1) adjusted tax basis, (2) book value, or (3) fair market value. ${ }^{236}$ Among these alternatives, use of fair market value inputs would best present the economic reality of the corporation's capitalization structure.

\section{a. Adjusted Tax Basis}

Adjusted tax basis offers one option to value the inputs in the debtto-equity ratio. Adjusted tax basis reflects "past tax treatment" of a corporation's assets and liabilities. ${ }^{237}$ The Treasury's proposed section 385 regulations from the early 1980s calculated the ratio by using the adjusted tax basis of a corporation's liabilities, excluding trade payables, over the adjusted tax basis of stockholders' equity. ${ }^{238}$ Similarly, section

232. See Universal Racquetball Rockville Ctr. Corp. v. Comm'r, 52 T.C.M. (CCH) 143, 148 (1986). See also Gibson, supra note 7, at 482 (noting the great ambiguity in determining the inputs into the debt-to-equity ratio because "different courts include different items in both the numerator and denominator of the ratio").

233. Greenaway \& Marion, supra note 24 , at 88.

234. See id. at 110 ("Lenders do not reasonably expect to be repaid from undercapitalized borrowers with no cash flow and poor credit.").

235. S. REP. NO. 91-552, at 140 (1969), as reprinted in 1969 U.S.C.C.A.N. 2027, 2172.

236. See discussion infra Parts III.C.2.a-c.

237. See Jesse V. Boyles \& Randolph J. Rush, The Regulations Under Section 385: A Review, Evaluation, and Suggested Approach, 27 VILL. L. REV. 52, 69 (1981-82) (“[A]djusted [tax] basis is primarily a reflection of the past tax treatment of assets.").

238. Supplementary Information to Proposed Regulations, 45 Fed. Reg. 18,957, 18,959 (Mar. 
163(j) utilizes adjusted tax basis to calculate the debt-to-equity ratio to prevent deductibility of interest paid to a related tax exempt or foreign entity. ${ }^{239}$ Thus, use of the adjusted tax basis of a corporation's debt and equity for proposed regulations under section 385 would be consistent with section 163(j). ${ }^{240}$ In addition, adjusted tax basis values could be more easily accessible than fair market value figures, which the Treasury noted would be difficult to determine for operating assets. ${ }^{241}$

Use of adjusted tax basis values in the debt-to-equity ratio, however, presents several disadvantages that outweigh the advantages. First, use of adjusted tax basis would be inconsistent with judicial opinions, which have generally used either fair market value or book value figures. ${ }^{242}$ Second, adjusted tax basis figures would not represent the economic reality of the capitalization of the corporation because adjusted tax basis reflects "past tax treatment" of a corporation's assets and liabilities. ${ }^{243}$ For instance, some assets, like goodwill or other intangibles, do not have an adjusted tax basis, which would distort the calculation. ${ }^{244}$ Finally, in commercial lending transactions, the borrower's tax basis is irrelevant to the lender's consideration of the borrower's assets and liabilities. ${ }^{245}$ Because the debt versus equity inquiry is ultimately a question of economic reality, ${ }^{246}$ economic reality should be the main focus of the Treasury's regulations. Adjusted tax basis does not necessarily portray the economic reality of a corporation; thus, adjusted tax basis should not

24, 1980).

239. See I.R.C. § 163(j) (2012).

240. But see Philip G. Cohen, Testing for Thin Capitalization Under Section 163(j): A Flawed Safe Harbor, 67 TAX LAW. 67, 67-68 (2013) (arguing fair market value, and not book or tax basis, is the proper measure in testing thin capitalization for purposes of section 163(j)).

241. Supplementary Information to Proposed Regulations, 45 Fed. Reg. 18,957, 18,959 (Mar. 24, 1980).

242. See Boyles \& Rush, supra note 237, at 68 ("The use of the adjusted basis of the corporation's assets in computing shareholders' equity may be criticized on the basis that it is inconsistent with the existing case law.").

243. See id. at 69 (stating that adjusted tax basis is "an inaccurate measure of capitalization and it has no necessary correlation to economic reality" and is "a reflection of the past tax treatment of assets"). See also Cohen, supra note 240, at 68 ("In many instances, the use of tax basis or book value in measuring assets will provide a distorted picture of the borrowing ability of the taxpayer in question.").

244. Boyles \& Rush, supra note 237, at 69 (asserting that some assets, such as goodwill, do not have adjusted tax basis, which "may substantially distort the equity portion of the debt-equity ratio"). See also Cohen, supra note 240, at 67 (noting that most taxpayers would elect to deduct research and development expenditures and therefore have no tax basis in these intangible assets).

245. Peter H. Blessing et al., N.Y. State Bar Ass'N Tax Section, Report on Certain Legislative Proposals Relating to the Section 163(J) Earnings StripPing Rules 10-11 (2003), http://old.nysba.org/Content/ContentFolders20/TaxLawSection/TaxReports/1037Report.pdf.

246. See supra notes 137-39 and accompanying text. 
be used to calculate the debt-to-equity ratio.

\section{b. Book Value}

While the Treasury's proposed regulations from the 1980s focused on adjusted tax basis, the Ninth Circuit asserts that book value of debt and equity should be calculate the debt-to-equity ratio. ${ }^{247}$ Additionally, rather than excluding trade payables and third-party debt from the ratio, "the total debt-to-equity ratio [comparing the total liabilities to the stockholders' equity] is the appropriate ratio to review in determining whether a corporation is too thinly capitalized." 248 The Tax Court has also used book values in evaluating thin capitalization. ${ }^{249}$

There are several advantages of using book values to calculate the ratio. Book values are readily available in the corporation's accounting records and are reported on corporate income tax returns, ${ }^{250}$ so utilizing book values eliminates the burden of duplicate records required for a fair market valuation. Using book values would also prevent the corporation from incurring costs associated with a formal valuation. ${ }^{251}$ Moreover, book values, based upon generally accepted accounting principles (GAAP), would likely produce more uniformity among taxpayers because "credit is ordinarily extended on the basis of certified financial statements rather than tax returns.",252

Although there are advantages to using book values as inputs into the ratio, book values may not necessarily portray the corporation's true economic capitalization. ${ }^{253}$ The net book value of equity could have little to do with a corporation's ability to achieve third-party lending. ${ }^{254}$ While it may appear that the use of fair market values would require duplicate records, companies are required to disclose the fair market value of debt, but not equity, in the notes to their financial statements. ${ }^{255}$ Further, the

\footnotetext{
247. Bauer v. Comm'r, 748 F.2d 1365, 1369 (9th Cir. 1984).

248. Id.

249. See Smithco Eng'g, Inc. v. Comm'r, 47 T.C.M. (CCH) 966, 970 (1984) (using unaudited financial statements to calculate high debt/equity ratios to hold that issuer was thinly capitalized).

250. Boyles \& Rush, supra note 237, at 70-71.

251. Antoon, supra note 136.

252. Boyles \& Rush, supra note 237, at 70.

253. CARNEY, supra note 14, at 95 ("Book value is an accounting artifact that frequently has no relationship to the economic value of a business. The book value of a company is a function of the value of its assets as recorded in its accounting records.... [F]requently book value begins to deviate from fair market value ... because the market value of such assets changes.").

254. Antoon, supra note 136.

255. JCT, supra note 29, at 91 ("From a balance sheet perspective, an instrument classified as debt will generally be recorded at historic cost with any accrued but unpaid interest also accounted
} 
Tax Court has noted that book values may not include goodwill, which should not be ignored in computing the value of a shareholder's capital investment in the corporation. ${ }^{256}$ Because book values do not illustrate the economic reality of the corporation, book values should not be used to calculate the debt-to-equity ratio.

\section{c. Fair Market Value}

Considering economic reality, fair market value offers the best option to value the inputs into the debt-to-equity ratio. Fair market value is "the price at which the property would change hands between a willing buyer and a willing seller, neither being under any compulsion to buy or sell and both having reasonable knowledge of relevant facts."257 Economic reality indicates that the courts should look to what a third party financial institution would use to loan funds to the corporation. ${ }^{258}$ In the marketplace, lenders are interested in the debt-to-equity level of a borrower based on the fair market value of a corporation because fair market value indicates the "intrinsic strength of the business to raise capital. ${ }^{, 259}$ In fact, in the proposed section 385 regulations from 1980, the Treasury noted that fair market values would technically be a more accurate figure than adjusted tax basis for the debt-to-equity ratio. ${ }^{260}$ Furthermore, the majority of courts have taken assets at fair market value when valuing the equity interest for the ratio. ${ }^{261}$ For example, the Second Circuit asserted: "[I]n the determination of debt-equity ratios, real values rather than artificial par and book values should be applied." 262

The fair market value of stockholders' equity can be computed either by netting the fair market value of assets against the fair market value of

\footnotetext{
for as a liability. The company, however, will be required to disclose the fair market value of the debt in the notes to its financial statements.").

256. See LaStaiti v. Comm'r, 41 T.C.M. (CCH) 511, 520 n.8 (1980) (“[T]he books would not necessarily reflect the full value of petitioner's investment in Associates... This business undoubtedly possessed substantial goodwill, and it cannot be ignored in computing the value of petitioner's capital investment in the corporation.").

257. Treas. Reg. § 1.170A-1(c)(2) (as amended in 2008).

258. See supra notes 11-14 and accompanying text.

259. Antoon, supra note 136.

260. Supplementary Information to Proposed Regulations, 45 Fed. Reg. 18,957, 18,959 (1980).

261. See William M. Goldstein, Corporate Indebtedness to Shareholders: "Thin Capitalization" and Related Problems, 16 TAX L. REv. 1, 19 (1960) ("The prevailing view seems to be that assets are to be taken at fair market value rather than at book value when valuing the equity interest in order to compute the [debt-to-equity] ratio."); McEvoy, supra note 145, at 2 (asserting that "the fair market value of assets and liabilities rather than their historical or book values should be used" in calculating the debt-to-equity ratio).
}

262. Kraft Foods Co. v. Comm'r, 232 F.2d 118, 127 (2d Cir. 1956). 
liabilities or by calculating the fair market value of the issuing corporation's outstanding stock. ${ }^{263}$ Some courts have included intangible assets that are not recorded in the accounting records of the corporation when calculating fair market value. ${ }^{264}$ Additionally, some courts have considered the going-concern value or the goodwill of an established business to test the adequacy of a corporation's capitalization. ${ }^{265}$ In extending credit, third-party lenders would likely take into consideration such intangible assets. ${ }^{266}$

However, the main disadvantage of using fair market value is the associated costs of a formal valuation. Requiring small, closely-held businesses, which are likely impacted by the debt versus equity issue, to pay for a formal valuation of their equity could prove expensive. ${ }^{267}$ Yet, the IRS has provided ample guidance for valuation experts of closelyheld corporations, so corporations should be able to seek out valuations at a reasonable cost. Moreover, as discussed above, ${ }^{268}$ recent cases

263. See Boyles \& Rush, supra note 237, at 70 (“[S]tockholders' equity is to be computed based upon fair market value,... [by either calculating] the sum of the fair market values of individual assets less the liabilities, ... [or by calculating] the fair market value of the corporation's outstanding stock.").

264. See Bulkley Dunton \& Co. v. Comm'r, 20 T.C.M. 660, 665 (1961) (considering the transfer of a highly reputable business name as an intangible asset caused the entity to not be thinly capitalized). Cf. Plantation Patterns, Inc. v. Comm'r, 462 F.2d 712, 722-23 (5th Cir. 1972), aff'g 29 T.C.M. (CCH) 817 (1970) (holding that intangible assets should not be included in the debt-toequity ratio unless convincing evidence show that the intangible assets have a direct, primary relationship to the well-being of the corporation, and that the intangible assets are something more than management skills expected of management in any corporation).

265. See Nye v. Comm'r, 50 T.C. 203, 215 (1968) (stating there existed "no reason why either the going-concern value or the goodwill of the established business should not be taken into account in testing the adequacy of the corporation's capitalization"); Murphy Logging Co. v. United States, 378 F.2d 222, 224 (9th Cir. 1967) (considering the intangibles of expectancy of future custom, integrity, and reputation for getting things done as extremely important to prevent the corporation from being "thinly" capitalized).

266. Cohen, supra note 240, at 85 ("Loans made by third party lenders would take such intangibles into consideration.").

267. See Rev. Rul. 59-60, 1959-1 C.B. 237 (outlining "the approach, methods and factors to be considered in valuing shares of the capital stock of closely held corporations ... on which market quotations are either unavailable or are of such scarcity that they do not reflect the fair market value"). The relevant factors include:

(a) [t]he nature of the business and the history of the enterprise from its inception; (b) $[t]$ he economic outlook in general and the condition and outlook of the specific industry in particular; (c) [t]he book value of the stock and the financial condition of the business; (d) [t]he earning capacity of the company; (e) [t]he dividend-paying capacity; (f) [w] hether or not the enterprise has goodwill or other intangible value; $(\mathrm{g})$ [s]ales of the stock and the size of the block of stock to be valued; [and] (h) [t]he market price of stocks of corporations engaged in the same or a similar line of business having their stocks actively traded in a free and open market, either on an exchange or over-the-counter.

Id.

268. See discussion supra Part II.B.2. 
regarding the debt versus equity issue have involved larger, international entities. If this trend continues, these larger entities should be able to afford formal valuations. Ultimately, "the measure of thin capitalization should reflect commercial reality, that is, the fair market value of the issuer's assets." 269

\section{Beneficial Effects of Proposing Regulations Under Section 385}

Proposing regulations under section 385 in regards to thin capitalization and the debt-to-equity ratio would accrue several advantages. The regulations would decrease litigation, fulfill congressional intent, increase predictability for the corporate taxpayer, increase consistency throughout the Code as well as with tax laws of foreign countries, and incentivize corporate officers to decrease debt in corporate capital structures.

\section{Decreased Litigation and Fulfilled Congressional Intent}

The proposed regulations under section 385 regarding thin capitalization would decrease litigation on the debt versus equity issue. Currently, section 385 and Notice 94-47 merely list possible factors to consider in the debt versus equity inquiry. ${ }^{270}$ The ambiguity surrounding the governing rule for debt versus equity characterization has resulted in decades of incongruent case law among the Tax Court and circuit courts. $^{271}$ Additionally, because the debt versus equity analysis involves a factual determination, the IRS generally will not provide guidance in the form of a letter ruling. ${ }^{272}$ However, the proposed regulations discussed above would establish an objective basis to analyze the debt versus equity issue. This objective basis, resulting in less ambiguity for the corporate taxpayer and the IRS, would promote judicial economy by decreasing litigation on this issue.

\footnotetext{
269. See Cohen, supra note 240 , at $87-88$.

270. See discussion supra Part II.A.3.

271. See discussion supra Part II.B.1.

272. Rev. Proc. 2015-3, 2015-1 I.R.B. 129, § 4.02(1).

Although it is generally inappropriate for the Service to issue a letter ruling on whether an interest in a corporation is stock or indebtedness, there may be instances in which the Service may issue a letter ruling. For example, the Service may issue a letter ruling with respect to an instrument issued by a domestic corporation if (i) the taxpayer believes that the facts strongly support the classification of the instrument as stock and (ii) the taxpayer can demonstrate that there are unique and compelling reasons to justify the issuance of a letter ruling.
} 
In addition, the proposed regulations would fulfill congressional intent. In legislative history from the codification of section 385, the Senate Finance Committee noted: "[I]t would be desirable to provide rules for distinguishing debt from equity in the variety of contexts in which [the distinction between debt and equity] can arise." ${ }^{273}$ Accordingly, Congress authorized the Secretary of the Treasury to prescribe regulations. ${ }^{274}$ Treasury regulations are particularly persuasive when "supported by declarations of congressional intent." 275 Furthermore, the Treasury frequently and efficiently issues regulations, which foregoes the moderate pace of Congress. ${ }^{276}$ Therefore, the Treasury's proposing regulations under section 385 would fulfill congressional intent.

\section{Increased Predictability}

In addition to decreasing litigation and fulfilling congressional intent, proposing section 385 regulations involving thin capitalization would also increase predictability for the corporate taxpayer. Commentators agree that the most significant problem with the multifactor debt versus equity test is its unpredictability. ${ }^{277}$ In general, the Code is considered one of the most "extensive, confusing, and unpredictable areas of law."278 Specifically, the lack of regulations under section 385 makes debt versus equity issues difficult to analyze because of the inconsistent case law and infrequent pronouncements from the IRS. ${ }^{279}$ As discussed above, ${ }^{280}$ the circuit courts do not agree on a particular list of factors for the debt versus equity analysis. Thus, the circuits' multifactor tests are "similar but not uniform."281 One commentator noted: "In practice the result of the debt-equity factors is not to provide a solution to the

\footnotetext{
273. S. REP. NO. 91-552, at 2170 (1969).

274. See id.

275. United States v. Stapf, 375 U.S. 118, 127 n.11 (1963).

276. Jason Quinn, Comment, Being Punished for Obeying the Rules: Corporate Tax Planning and the Overly Broad Economic Substance Doctrine, 15 GEO. MASON L. REv. 1041, 1076 (2008).

277. Greenaway \& Marion, supra note 24, at 80-81.

278. Quinn, supra note 276, at 1073.

279. Debt v. Equity Considered in Recent Non-Binding Issuances, 19 J. TAX'N F. INSTITUTION 59, 64 (2005) (noting the "heterogeneous case law and the piecemeal nature of IRS pronouncements in the area"). See also Greenaway \& Marion, supra note 24, at 74 ("[The] classic multifactor test ... is unpredictable. It uses some factors that are hard if not impossible to measure. Other factors offer a veneer of objectivity but no baseline against which to measure. Finally, there is no agreed way for practitioners and judges to weigh one factor against another or all the factors together.").

280. See discussion supra Part II.B.1.

281. Cohen, supra note 240 , at 67.
} 
problem but rather to foster uncertainty. Flexibility of a rule always favors the IRS more than taxpayers because most taxpayers are scared by the lack of clear rules and because the IRS can argue different ways in different cases." 282

Predictability would result from the objective calculation of the debtto-equity ratio to determine if the borrowing corporation is thinly capitalized. ${ }^{283}$ While other debt versus equity factors require high levels of subjectivity from the courts, ${ }^{284}$ thin capitalization — determined by the debt-to-equity ratio-offers objectivity to analysis of the issue. Therefore, the corporate taxpayer would be able to rely on the proposed regulations, which would utilize fair market values to calculate the debtto-equity ratio. If the corporate taxpayer's debt-to-equity ratio is reasonable for its industry, then the taxpayer should be able to predict that the IRS, as well as the courts, would support its interest deductions.

Furthermore, section 385 regulations would provide the corporate taxpayer with a defined framework on which to rely because final Treasury regulations consistent with the corresponding statute have the force of law. ${ }^{285}$ The Code gives the Secretary of the Treasury broad authority to prescribe regulations for enforcement of the Code. ${ }^{286}$ As a result, "Treasury regulations must be sustained unless unreasonable and plainly inconsistent" 287 with the Code. However, the proposed regulations must be adopted in final form to have full legal effect. ${ }^{288}$ Here, section 385 regulations would be considered legislative regulations, ${ }^{289}$ which are governed by the Administrative Procedure Act

\footnotetext{
282. Jasper L. Cummings, Jr., Pepsico and Debt Equity, 138 TAX Notes 111 (2013).

283. See discussion supra Part II.B.3.

284. See discussion supra Part III.A.

285. See Deshler Hotel Co. v. Busey, 36 F. Supp. 392, 395 (S.D. Ohio 1941), aff'd, 130 F.2d 187 (6th Cir. 1942) (asserting that the Treasury regulation in question, "in so far as it is authorized by the terms of the act, must be deemed to have been given legislative approval, and to that extent, it is to be considered as a part of the law"). See also Quinn, supra note 276, at 1079 ("If the taxpayer cannot determine the scope of the standards by which his actions will be judged, he cannot tailor his actions to conform to the law.").

286. I.R.C. § 7805(a) (2012) (“[T]he Secretary shall prescribe all needful rules and regulations for the enforcement of this title, including all rules and regulations as may be necessary by reason of any alteration of law in relation to internal revenue.").

287. United States v. Cartwright, 411 U.S. 546, 557 (1973) (quoting Comm'r v. S. Tex. Lumber Co., 333 U.S. 496, 501 (1948)).

288. I.R.S. Chief Couns. Notice CC-2003-014 (May 8, 2003) ("Proposed regulations have no legal effect unless and until they are adopted.").

289. See Leandra Lederman \& Stephen W. MaZZa, Tax Controversies: Practice and PROCEDURE 31 ( $3 \mathrm{~d}$ ed. 2009) (noting that legislative regulations, distinguished from interpretive regulations, are "released under an express delegation of Congressional authority in the particular Code section they address"). See also I.R.C. § 385(a) ("The Secretary is authorized to prescribe such regulations as may be necessary or appropriate to determine whether an interest in a
} 
(APA) ${ }^{290}$ The APA requires a thirty-day notice and comment period before proposed regulations are published in their final form in the Federal Register. ${ }^{291}$

Once finalized, the proposed regulations would be consistent with the Code for several reasons. First, the debt-to-equity ratio is one of the five factors listed in section $385,{ }^{292}$ so further defining this factor would be consistent with the congressional intent of section $385 .{ }^{293}$ Second, the proposed regulations would not define thin capitalization as the only factor to the analysis. Rather, the proposed regulations would define thin capitalization as a principal factor for debt versus equity characterization. ${ }^{294}$ Thus, the Treasury would have the option to set forth other factors to be taken into account for the debt versus equity analysis in accordance with section 385(b). ${ }^{295}$

\section{Increased Consistency}

In addition to increasing predictability, the proposed regulations would also increase consistency among court rulings, within the Code itself, and with tax laws of foreign countries. First, with objective guidance from the proposed regulations, courts would be less likely to subjectively arrive at their conclusions. Courts are tempted to "bend any available tool" to disallow disproportionate tax benefits, so courts are likely to disallow interest deductions on purported debt. ${ }^{296}$ In addition, over time, courts have been inconsistent in their calculation of the debtto-equity ratio. ${ }^{297}$ Several courts have used book value, ${ }^{298}$ while others have used fair market value. ${ }^{299}$ Because the proposed regulations would establish that fair market value is the standard for calculating the debt-to-

\footnotetext{
corporation is to be treated for purposes of this title as stock or indebtedness (or as in part stock and in part indebtedness).”).

290. 5 U.S.C. $\$ 553$ (2012).

291. See id. §553(b)(3), (d).

292. See I.R.C. $\S 385(b)(3)$.

293. See S. REP. No. 91-552, at 2169-76 (1969).

294. See discussion supra Part III.C.

295. See I.R.C. § 385(b) ("The regulations prescribed under this section shall set forth factors which are to be taken into account in determining with respect to a particular factual situation whether a debtor-creditor relationship exists or a corporation-shareholder relationship exists.").

296. See Adams, supra note 87.

297. See Liflans Corp. v. United States, 390 F.2d 965, 969 (Ct. Cl. 1968) (noting that the plaintiff's debt-to-equity ratio depended "on when computed and whether the book value or the market value of the assets is used").

298. See discussion supra Part III.C.2.b.

299. See discussion supra Part III.C.2.c.
} 
equity ratio, this ambiguity would be resolved.

Second, the proposed regulations would increase consistency within the Code. Several provisions of the Code utilize fair market value, such as in the calculation of initial tax basis, and capital gains and losses. ${ }^{300}$ Similarly, the proposed regulations would use fair market value to calculate the issuing corporation's debt and equity. Thus, the proposed regulations would increase consistency between section 385 and other sections of the Code that utilize fair market value.

Some may argue that using fair market value for the debt-to-equity ratio, rather than increase consistency, would decrease consistency. Section 163(j) uses adjusted tax basis, not fair market value, to implement a 1.5 to 1 safe harbor debt-to-equity ratio. ${ }^{301}$ As a result, the proposed regulations may decrease consistency between sections 385 and 163(j). However, some commentators assert that section 163(j) should use fair market value rather than adjusted tax basis in its calculation. ${ }^{302}$ After balancing the arguments, fair market value appears to be the better approach to increase consistency within the Code.

Finally, the proposed regulations would increase consistency between the Code and tax laws of other countries because the proposed regulations will reach a broader base of corporate taxpayers. In the mid1990s, less than one-third of European countries imposed thin capitalization rules. ${ }^{303}$ By 2005, three-fifths of European countries had imposed such rules. ${ }^{304}$ These anti-abuse provisions restrict "interest deductibility for loans provided to a domestic corporation by a foreign parent.",305

Tax penalties are usually enforced if the domestic corporation's debtto-equity ratio is above a fixed ratio, labeled as a safe haven or safe harbor. ${ }^{306}$ For instance, in Australia, the interest deduction for indebtedness is denied when an entity's worldwide debt-to-equity ratio exceeds 3 to $1^{307}$ Similarly, in Japan, "when liabilities exceed three times the capital held by the foreign controlling shareholder, the amount

\footnotetext{
300. See Cohen, supra note 240 , at 67.

301. See I.R.C. § 163(j) (2012).

302. See generally Cohen, supra note 240, at 67 (arguing that fair market value, and not book or tax basis, is the proper measure in testing thin capitalization for purposes of section 163(j)).

303. Thiess Buettner et al., The Impact of Thin-Capitalization Rules on the Capital Structure of Multinational Firms, 96 J. PUB. ECON. 930, 930 (2012).

304. Id.

305. Id. at 931 .

306. Id.

307. JCT, supra note 29, at 95.
} 
of interest payable on the excess amount is not deductible." 308

In the United States, section 163(j) is cited as the U.S. "thin capitalization" safe harbor rule. ${ }^{309}$ Yet, section 163(j) applies to a narrow subset of U.S. corporate taxpayers that have a debt-to-equity ratio in excess of 1.5 to 1 , pay "disqualified interest," and have "excess interest expense." 310 However, section 385 applies to all corporate taxpayers. ${ }^{311}$ If the proposed regulations are finalized, then the U.S. thin capitalization rules would include not only section 163(j) but also section 385 . Therefore, the proposed regulations under section 385 would increase consistency between U.S. tax laws and those of other countries.

\section{Corporations Incentivized to Decrease Debt in Capital Structures}

In addition to decreasing litigation and increasing predictability and consistency, proposing regulations under section 385 would also incentivize corporations to decrease debt in their capital structures. Corporations generally seek to support business at the lowest cost of capital. $^{312}$ Because of the advantageous interest deduction associated with debt instruments, corporate taxpayers have a strong incentive to treat cash advances from corporate parents or individual shareholders as debt. ${ }^{313}$ The proposed regulations would likely change how corporations finance their capital structures. Rather than taking advantage of inconsistent case law to increase debt in their capital structures, ${ }^{314}$ corporate taxpayers would be cautious of a capital structure with excessive debt because the debt-to-equity ratio would be an established, principal factor in the analysis. Indeed, at least one empirical study shows that rules limiting thin capitalization change a taxpaying corporation's behavior because the rules reduce a corporation's tax incentive to use debt with a closely-held affiliate. ${ }^{315}$

\footnotetext{
308. Id.

309. See Buettner et al., supra note 303, at 932.

310. See I.R.C. § 163(j) (2012).

311. See I.R.C. $§ 385$. Section 385 is in Subchapter C, entitled "Corporate Distributions and Adjustments."

312. JCT, supra note 29, at 64 ("A business (the issuer of debt or equity) typically wishes to obtain capital at the lowest cost.").

313. See discussion supra Part II.A.1.

314. Lee A. Sheppard, News Analysis: Toward Straightforward Section 385 Guidance, 65 TAX NOTES 664 (1994) (containing the statement that the lack of section 385 regulations "embolden[s] taxpayers to push the limits of their interpretation of the case law").

315. See Buettner et al., supra note 303, at 937 ("[O]ur results indicate that thin-capitalization rules can effectively reduce the tax-incentive for internal debt and, thus, curb tax planning by multinational firms ....").
} 
Since 2008, there have been efforts to deleverage - or decrease debt within - business structures because excessive debt is blamed as the main cause of the 2008 financial crisis. ${ }^{316}$ Because the proposed regulations regarding thin capitalization would impact the behavior of corporate taxpayers, the proposed regulations would aid in the efforts for corporations to deleverage their capital structures to avoid another financial crisis.

In addition, in September 2014, the IRS issued Notice 2014-52 in regards to corporate inversions. ${ }^{317}$ In these transactions, a U.S. entity merges with a foreign company and then changes its place of domicile to the country in which the foreign company is located. ${ }^{318}$ Such corporate inversions are attractive to U.S. corporations because of foreign countries' lower tax rates. $^{319}$ As a result of an inversion, a U.S. corporation may issue debt to its foreign parent to deduct interest. ${ }^{320}$ Regarding this possibility, Notice 2014-52 states:

The Treasury Department and the IRS expect to issue additional guidance to further limit inversion transactions .... In particular, the Treasury Department and the IRS are considering guidance to address strategies that avoid U.S. tax on U.S. operations by shifting or "stripping" U.S.-source earnings to lower-tax jurisdictions, including through intercompany debt. Comments are requested regarding the approaches such guidance should take.

To address corporate inversions, lawmakers have considered section 385 regulations, which would limit the amount of debt a company could

\footnotetext{
316. See Greenaway \& Marion, supra note 24, at 93-94.

Some consider the [Internal Revenue] Service's work on debt-equity cases to be part of the larger regulatory effort towards deleveraging the U.S. economy. Excessive debt was blamed as a main culprit behind the 2008 financial crisis and ensuing great recession.... With the "deleveraging" conventional wisdom firmly planted in the minds of the informed public and policymakers, it would not be surprising to find the [Internal Revenue] Service - with the benefit of hindsight - attacking what proved to be overly optimistic debt financing arrangements.

317. I.R.S. Notice 2014-52, 2014-42 I.R.B. 712.

318. Maureen Farrell \& Damian Paletta, Obama Explores Tax-Code Weapons in InversionMerger Fight, WALL ST. J. (Aug. 8, 2014, 12:09 AM), http://www.wsj.com/articles/obama-explorestax-code-weapons-in-inversion-merger-fight-1407458279.

319. Id.

320. See J. Clifton Fleming, Jr. et al., Getting Serious About Cross-Border Earnings Stripping: Establishing an Analytical Framework, 93 N.C. L. REV. 673, 678-80 (2015) (“A major reason for U.S. MNEs [multinational enterprises] to invert is to create large amounts of debt owed to foreign related parties and then to erode the U.S. income tax base by means of deductible interest payments on that debt, a maneuver included under the rubric of earnings stripping.").

321. I.R.S. Notice 2014-52, 2014-42 I.R.B. 712.
} Id. 
use for tax deductions. ${ }^{322}$ Here, the proposed regulations regarding thin capitalization would aid in the effort to decrease corporate inversions because the proposed regulations add objectivity to the facts and circumstances test. If a corporate taxpayer is considering a corporate inversion under the status quo, the corporate officers would likely think that the corporation could support its position due to the wide flexibility of the debt versus equity factors test. However, under the proposed regulations, the corporate officers would be forced to focus on economic reality by honing in on the debt-to-equity ratio. As a result, the proposed regulations would incentivize corporations to decrease debt in their capital structures.

\section{CONCLUSION}

The debt versus equity treatment of cash advances between shareholders and a corporation has caused decades of litigation, resulting in inconsistent rulings and a plethora of considered factors. Courts should look to thin capitalization with the associated debt-to-equity ratio to objectively evaluate the economic reality of the corporation's financial condition.

To fulfill Congress' intent in enacting section 385, the Treasury should propose regulations to provide more guidance to corporate taxpayers regarding thin capitalization. The regulations should not impose a safe harbor rule because a reasonable debt-to-equity ratio in one industry may be unreasonable in another industry. Rather, the regulations should establish the calculation of the debt-to-equity ratio based upon fair market value of the issuing corporation's liabilities and shareholders' equity. Such an approach is comparable to the approach of third party lenders.

Section 385 regulations regarding thin capitalization and the debt-toequity ratio would solve many shortcomings of the status quo. Treasury's guidance would provide more certainty to taxpayers and would promote judicial economy in focusing on the economic reality of the situation rather than an endless list of factors, several of which are irrelevant in the current financial marketplace. In addition, Treasury's

322. Andrew Velarde, Debt Reclassification or Interest Limits Possible for Inversions. (Section 7874 - Expatriated Entities and Foreign Parents), 2014 TAX Notes TODAY 210-1 (2014). See also Andrew Velarde, Targeted 385 Stripping Guidance Is Path of Least Resistance, TAX ANALYSTS (Dec. 29, 2014), http://www.taxanalysts.com/www/features.nsf/Features/811E7B26FEF241AE85 257DBD005FBC72?OpenDocument (describing the Treasury's advantages and disadvantages of creating regulations regarding corporate inversions under section 385 rather than section 163(j)). 
guidance would increase predictability and consistency. The proposed regulations would also incentivize corporations to de-leverage their businesses.

Ultimately, the proposed regulations would bring to the forefront thin capitalization, a principal factor in the debt versus equity analysis. Thin capitalization and the debt-to-equity ratio focus on the economic reality of the corporation's capital structure. As international financing continues to increase, Treasury's guidance on these issues would increase predictability for the taxpayer and consistency for the lawmaker. 